\title{
A hierarchical approach on groundwater-surface water interaction in wetlands along the upper Biebrza River, Poland
}

\author{
C. Anibas ${ }^{1}$, B. Verbeiren ${ }^{1}$, K. Buis ${ }^{2}$, J. Chormański ${ }^{3}$, L. De Doncker ${ }^{4}$, T. Okruszko ${ }^{3}$, P. Meire ${ }^{2}$, and O. Batelaan ${ }^{1,5}$ \\ ${ }^{1}$ Department of Hydrology and Hydraulic Engineering, Vrije Universiteit Brussel, Pleinlaan 2, 1050 Brussels, Belgium \\ ${ }^{2}$ Department of Biology, Ecosystem Management Research Group, University of Antwerp, Universiteitsplein 1c, \\ 2610 Antwerp, Belgium \\ ${ }^{3}$ Division of Hydrology and Water Resources, Department of Hydraulic Engineering, Warsaw University of Life Sciences, \\ ul. Nowoursynowska 159, 02-776 Warsaw, Poland \\ ${ }^{4}$ Civil Engineering Department, Hydraulics Laboratory, Ghent University, Sint-Pieternieuwstraat 41, 9000 Ghent, Belgium \\ ${ }^{5}$ Department of Earth and Environmental Sciences, K. U. Leuven, Celestijnenlaan 200e, 3001 Leuven, Belgium
}

Correspondence to: C. Anibas (canibas@ vub.ac.be)

Received: 5 September 2011 - Published in Hydrol. Earth Syst. Sci. Discuss.: 27 October 2011

Revised: 26 May 2012 - Accepted: 27 June 2012 - Published: 27 July 2012

\begin{abstract}
As recognized in the European Water Framework Directive, groundwater-dependent wetlands and their diverse ecosystems have important functions which need to be protected. The vegetation in such habitats is often dependent on quality, quantity and patterns of river discharge and groundwater-surface water interaction on a local or reach scale. Since groundwater-surface water exchange studies on natural rivers and wetlands with organic soils are scarce, more functional analysis is needed. To this end we combined different field methods including piezometer nests, temperature as tracer and seepage meter measurements. Some of these measurements were used as inputs and/or as validation for the numerical 1-D heat transport model STRIVE. In transient mode the model was used to calculate spatially distributed vertical exchange fluxes from temperature profiles measured at the upper Biebrza River in Poland over a period of nine months. Time series of estimated fluxes and hydraulic head gradients in the hyporheic zone were used to estimate the temporal variability of groundwater-surface water exchange.

This paper presents a hierarchical approach for quantifying and interpreting groundwater-surface water interaction in space and time. The results for the upper Biebrza show predominantly upward water fluxes, sections of recharge, however, exist along the reach. The fluxes depend more on hydraulic gradients than on riverbed conductivity. This indicates that the fluvio-plain scale is required for interpreting
\end{abstract}

the exchange fluxes, which are estimated on a local scale. The paper shows that a conceptual framework is necessary for understanding the groundwater-surface water interaction processes, where the exchange fluxes are influenced by local factors like the composition of the riverbed and the position of the measurement on a local scale, and by regional factors like the hydrogeology and topography on a fluvio-plain scale. The hierarchical methodology increases the confidence in the estimated exchange fluxes and improves the process understanding. The accuracy of the measurements and related uncertainties, however, remain challenges for wetland environments. Gaining quantitative information on groundwatersurface water interaction can improve modeling confidence and as a consequence helps to develop effective procedures for management and conservation of valuable groundwater dependent wetlands.

\section{Introduction}

Groundwater-surface water exchange processes take place in the hyporheic zone, the area of saturated sediments beneath and beside streams, rivers and wetlands where groundwater and surface water is actively mixed (Brunke and Gonser, 1997; Boulton et al., 1998; Hayashi and Rosenberry, 2002; Sophocleous, 2002). The processes observed in the hyporheic zone are characterized by significant variability in 
both time and space (Triska et al., 1993; Constantz, 1998) and by relative strong biogeochemical activity (McClain et al., 2003; Smith, 2005). The complexity and uncertainty surrounding river research and management reflects the need to develop new or more refined tools and methods (Vaughan et al., 2009).

The purpose of this article is to quantify the hyporheic exchange fluxes in space and time for a section of the Biebrza River, Poland. A combination of different methods (Hunt et al., 1996; Weight and Sonderegger, 2001; Kalbus et al., 2006) is applied, including the use of hydraulic gradients, seepage meters and most prominent, the thermal method. With this approach we overcome limitations of each individual field method and provide a robust first level investigation of groundwater-surface water interacton for wetland environments.

For the understanding of hydro-ecological characteristics of wetlands we need to reliably identify and quantify the relevant interaction processes and vice versa. Therefore, we hypothesize that the magnitude and variation of fluxes in the hyporheic zone can be examined on a local scale (determined by local factors like composition of the riverbed, bathymetry, apparent surface water and groundwater temperatures) and extrapolated to a reach scale. Riverine wetland functioning is seen as dependent on the groundwater-surface water interaction at the larger fluvio-plain scale; consequently, we assume that groundwater-surface water interaction is dependent on regional factors such as topography, morphology, climate and hydrogeology.

The interaction processes between groundwater and surface water are based on the concept of connectivity, an emerging topic both in hydrological (Bracken and Croke, 2007; Lexartza-Artza and Wainwright, 2009) and ecological sciences (Pringle, 2001; Tetzlaff et al., 2007; Boulton et al., 2010). Hydrological connectivity refers to physical linkages of water in different catchment compartments such as rivers and adjacent wetlands (Bracken and Croke, 2007). Connectivity allows the exchange of water, solutes and dissolved matter and as a consequence energy transfer across the riverine landscape (Ward, 1997). The exchange of water strongly determines hydrogeochemical contact times, reaction rates, retention and feedback processes (Fisher et al., 1998; McClain et al., 2003; Buis et al., 2008).

Ecological landscape connectivity is defined as a functional relationship among habitat patches owing to the spatial contagion of biotopes and responses of organisms to the structure of the landscape (With et al., 1997). The supply of exfiltrating groundwater and the presence of shallow groundwater tables is essential for the maintenance of groundwater dependent wetlands and their habitat connectivity (Succow and Joosten, 2001; Ovaskainen and Hanski, 2004). The vegetation in such environments is often found to depend on the quality, quantity and the pattern of river discharge and groundwater-surface water interaction (Wassen and Joosten, 1996; Batelaan et al., 2003) on a local or reach scale. Groundwater-surface water interaction thus constitutes an important link between the river, its wetlands and the surrounding catchment.

Virtually all European wetlands are constantly influenced by land use changes, land reclamation, succession processes and habitat fragmentation (Tockner and Stanford, 2002; Hooftman et al., 2003; Smolders et al., 2010), leading to environmental degradation processes like desiccation, acidification or eutrophication (Lamers et al., 2002; Smolders et al., 2006; Van Diggelen et al., 2006). Reliable estimates of groundwater flow into a wetland and the understanding of interactions with other system compartments like surface water, unsaturated zone and organisms play a key role in evaluating the structure of stream systems (Sophocleous, 2002), the sustainability of their wetlands and the conservation of biodiversity (Schot and Winter, 2006).

Various national and international regulations like the European Water Framework Directive (European Commission, 2000) mandate the protection of linked groundwatersurface water systems. To comply with these regulations, integrated hydrologic and ecosystem models (Anderson and Wilson, 2004; Smith, 2005; Buis et al., 2008) are vital for the development of environmental standards and management schemes for the maintenance, protection and restoration of river catchments. Since the assessment of fluxes across the groundwater-surface water interface is important for the examination of related biogeochemical processes, their reliable quantification is an important component of these models.

Groundwater-surface water exchange processes are plagued with heterogeneity and scale problems (Woessner, 2000; Becker et al., 2004; Kalbus et al., 2008), their quantification on a local and reach scale challenging hydrologic sciences for decades. Uncertainties are related to variations of the hydromorphological and physical properties of the riverbed, the riparian zone and the underlying aquifer (Conant, 2004; Fleckenstein et al., 2006; Schornberg et al., 2010). A framework for improved estimation methods for exchange processes is therefore required.

Temperature is a dominant moderator of almost all biological and chemical processes, making it an important ecological parameter. Temperature can also be used as a natural tracer for the detection of groundwater-surface water exchange (Anderson, 2005; Kalbus et al., 2006; Constantz, 2008). The method has proved to be reliable (Lautz, 2010; Ferguson and Bense, 2011), not least because gathering of thermal data, parameter estimation, establishment of model boundary conditions and calibration are fairly simple (Anibas et al., 2009). Different methodologies have been applied (Anderson, 2005; Kalbus et al., 2006), but most commonly exchange rates have been quantified by inverse modeling of temperature profiles measured in riverbeds (Schmidt et al., 2006; Anibas et al., 2009, 2011). Various studies were performed on sites where the riverbed is composed of sand or gravel (Conant, 2004; Anibas et al., 2011); applications on sites dominated by peat soils are scarce. The application of 
the thermal method represents a point estimate (Becker et al., 2004); the spatial interpolation of distributed sets of these estimates is described in the literature (Schmidt et al., 2007; Anibas et al., 2011).

We gathered riverbed temperature profiles in "roaming surveys" (Keery et al., 2007) and continuously monitored river and riverbed temperatures to determine groundwatersurface water interaction by applying the physically based numerical heat transport model STRIVE (STReam RIVer Ecosystem; Buis et al., 2008). The model is used to calculate vertical flux rates in a spatial and temporal distribution by transient thermal simulations. Using GIS techniques, exchange patterns can be shown and the calculation of net mass fluxes across the interface between groundwater and surface water on a reach scale is possible. Statistical analysis show the influence of geo- and hydromorphology and riverbed heterogeneity on groundwater-surface water exchange on a fluvio-plain scale (Woessner, 2000; Vaughan et al., 2009).

The use of the thermal method has a limited temporal resolution; methods based on hydraulic head using standpipes, piezometer nests and boreholes (Cey et al., 1998; Baxter et al., 2003) can determine exchange fluxes with a high temporal resolution. We installed a series of piezometers to detect groundwater-surface water interaction by analyzing time series data of hydraulic and temperature gradients. The piezometers were also used for the determination of hydraulic conductivities of the riverbed (Lapham, 1989) by performing slug tests (Fetter, 2001) and by combining measurements of head gradients and simulations of the STRIVE model.

Seepage meters finally offer the possibility to measure the exchange flux directly (Lee, 1977), but also show uncertainties in the estimated fluxes related to the technical operation in the field (Murdoch and Kelly, 2003). We used seepage meter for a cross-validation of the results of the thermal and the head based methods.

\section{Field site}

The study area is situated along the Biebrza River $\left(22^{\circ} 30^{\prime}-\right.$ $23^{\circ} 60^{\prime}$ E, $53^{\circ} 30^{\prime}-53^{\circ} 75^{\prime}$ N, Fig. 1) in the Podlaskie Voivodeship, Poland, around $230 \mathrm{~km}$ north east of Warsaw. A small part of the catchment area of $7057 \mathrm{~km}^{2}$ is located in Belarus. The Biebrza River, a right sided tributary of the Narew River, comprises a river reach of $170.6 \mathrm{~km}$ with an average discharge of $39.2 \mathrm{~m}^{3} \mathrm{~s}^{-1}$ at its outlet. The Biebrza River is one of the few natural lowland river systems of this size in Europe (Pałczyński, 1984; Wassen and Joosten, 1996). With an area of $592 \mathrm{~km}^{2}$, occupying most of the alluvial flood plains, the Biebrza National Park forms a wetland of worldwide significance, protected by the United Nations (Ramsar Convention Secretariat, 2008) and by the European Union as a Natura 2000 habitat (European Commission, 1992). The site is the habitat of valuable river marshes and peat lands including

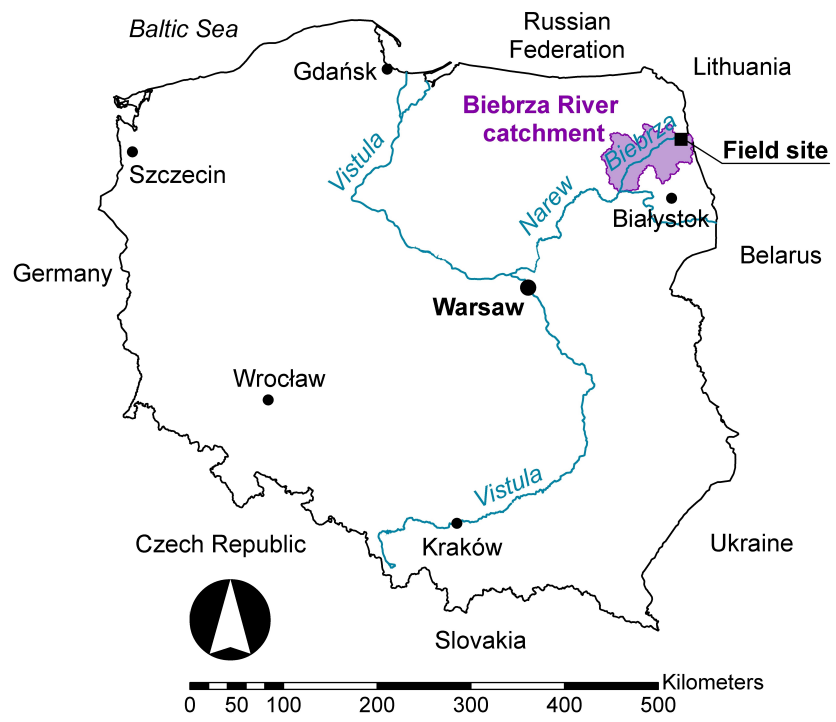

Fig. 1. Location of the Biebrza River catchment in Poland.

highly threatened plant and animal species, including the orchid Liparis loeselii and the Aquatic Warbler (Acrocephalus paludicola), respectively. As a hydro-ecological system, the Biebrza River finally serves as a reference area for restorations of managed wetlands (Wassen et al., 2006).

Geomorphologically, the Biebrza Valley is an extensive depression formed during the last glaciations. The morainic plateau outside the fluvial plain is composed of heterogeneous loamy sand deposits. The flat alluvial valleys are filled with thick deposits of fluvioglacial sands and gravels which are covered by a variety of organic soils. The structure of the organic soils is determined by the location of the river within the valley and the associated vegetation.

The Biebrza Valley is divided into three subcatchments (Żurek, 1984), the Upper Catchment, the Middle Catchment, and the Lower Catchment, characterized by different hydrological regimes (Byczkowski and Kiciński, 1984) and groundwater-surface water interaction (Okruszko et al., 2006; Chormański et al., 2009). The Upper Catchment, reaching from the springs of the Biebrza River to the village of Sztabin, is a $48 \mathrm{~km}$ long $1-3 \mathrm{~km}$ wide valley (Fig. 2) covering $846 \mathrm{~km}^{2}$. The topographic elevation of the Biebrza River valley varies between 110 and $130 \mathrm{~m}$ a.m.s.l. (above mean sea level), while the adjacent morainic plateau and the outwash plain varies between 130 and $180 \mathrm{~m}$ (Żurek, 1984).

Whereas the valley is narrow and steep close to the spring, the Biebrza River soon becomes a meandering stream which flows through a flat ice-marginal valley. The morainic uplands adjacent to the alluvial plain function as a regional groundwater recharge area and drain the surrounding plateau and the outwash plain towards the river (Pajnowska and Wiencław, 1984). Groundwater flow is influenced by the highly heterogeneous subsurface; it is focused at hydrogeologic windows and seeps out in the Biebrza valley. The peat 


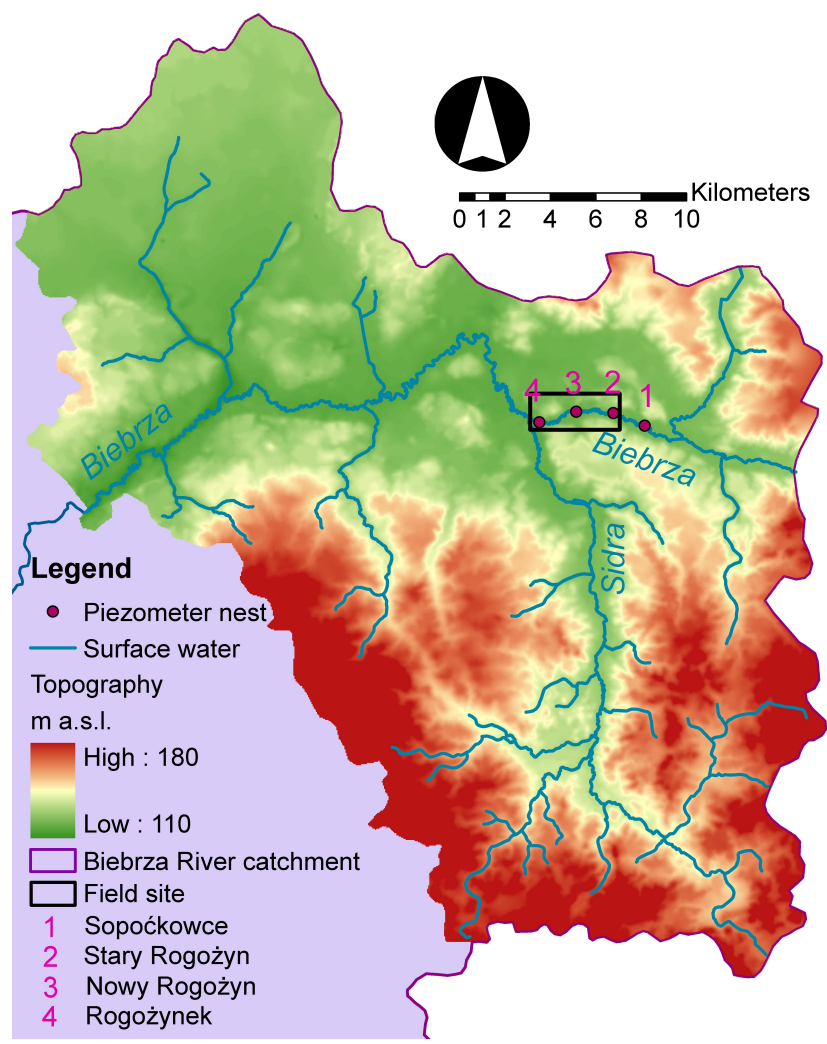

Fig. 2. Digital elevation model of the Upper Catchment of the Biebrza River. The dots indicate the locations of the piezometer nests. The black box indicates the river section where the T-stick measurements have been performed.

lands therefore are mostly groundwater fed; however, during spring freshets surface water also infiltrates the alluvia.

Crossed by ditches of abandoned land reclamation systems, the valley of the upper catchment is filled with deposits of varying peat soils of thicknesses of 2 to $5 \mathrm{~m}$. Together with the underlying fluvioglacial gravels and sands, the peat layer forms an unconsolidated aquifer. Glacial tills (Pajnowska and Wiencław, 1984; Ber, 2005), however, locally separate the sand and gravel layers, creating confined aquifers of varying extent and resulting in a complex local hydrogeology. The hydrogeological base of the Biebrza catchment consists of Tertiary marls at approximately 0 to $-40 \mathrm{~m}$ a.s.l.

The Biebrza River catchment is located in the subcontinental/subboreal climate zone with a yearly average temperature of $6.8^{\circ} \mathrm{C}$. The average annual precipitation ranges from 550 to $700 \mathrm{~mm} \mathrm{yr}^{-1}$, the evapotranspiration between 460 and $480 \mathrm{~mm} \mathrm{yr}^{-1}$ (Kossowska-Cezak, 1984). Given the low population density of the area, the current land cover in the morainic uplands consists mainly of arable land and remnants of the natural oak-beech forests. Low lying areas of the catchment are cultivated in an extensive manner as meadows and pastures. The alluvial plains show reed vegetation in the center of the valley and sedges closer to the slope crack. The slope crack is the break of the slope between the valley wall and the valley floor, indicated by the dashed line in Fig. 3.

The hydrological regime of the river in the upper catchment is characterized by a sequence of flood events which are limited in extent by the geomorphologic boundaries of the floodplain (i.e. the slope crack). Floods occur regularly after snowmelt in early spring. The late spring/early summer periods are characterized by low flow, whereas summer rain storms occasionally create flood peaks. During the dry periods, most of the Biebrza valley is groundwater fed. The spring inundations are only partly caused by river flooding; groundwater seepage and snowmelt water are present across $80 \%$ of the valley width (Chormański et al., 2011). At the mouth of the Upper Catchment at Sztabin, the average flow is $4.83 \mathrm{~m}^{3} \mathrm{~s}^{-1}$ (Chormański and Batelaan, 2011). At field location No. 4 (Fig. 2), the average discharge during the examined period was, with an estimated value of $0.31 \mathrm{~m}^{3} \mathrm{~s}^{-1}$, still much lower.

The characteristic low-productive fens are widely abundant in the alluvial plains (Oświt, 1994; Wassen and Joosten, 1996), but the succession of shrubs and forests is progressing (Pałczyński, 1985). Fen-bog transition is stimulated by enhanced infiltration of local precipitation following a subtle lowering of the surface water level of the Biebrza River. Caused by mechanization and rural exodus, the once extensively used areas on the flood plain undergo succession processes. This so-called shrub encroachment (Wassen and Joosten, 1996) results in increased evapotranspiration.

The examined river stretch is located in the upper catchment between the villages Sopoćkowce (Fig. 2, No. 1) upstream and Rogożynek (Fig. 2, No. 4) at the downstream end of the section. The majority of the presented measurements were performed between point No. 2 (Stary Rogożyn) and No. 4. The length of the river section is $5670 \mathrm{~m}$, and the average absolute elevation of the water level at No. 2 and 4 is 119.9 and $119.4 \mathrm{~m}$ a.s.l., respectively. The average slope of the riverbed was estimated as $0.23 \%$; the river has a width of about 6-8 $\mathrm{m}$ and an average depth of $1.1 \mathrm{~m}$ along the examined reach. The Biebrza River is free flowing along the entire reach; the river channel is characterized by a variety of cross-sections with steep banks. During low flow in summer, the Manning coefficient for this river stretch is about 0.12 (De Doncker et al., 2009). The riverbed is composed of peat of varying consistency; the banks mostly are covered with reed plants.

\section{Methodology}

Since the wetlands around the Biebrza River are protected, field methods which are not intrusive or immersive are preferred for the investigation. We applied a set of different field methods to quantify the groundwater-surface water interaction including methods based on hydraulic head, slug tests and seepage meters. The main method which was applied is 


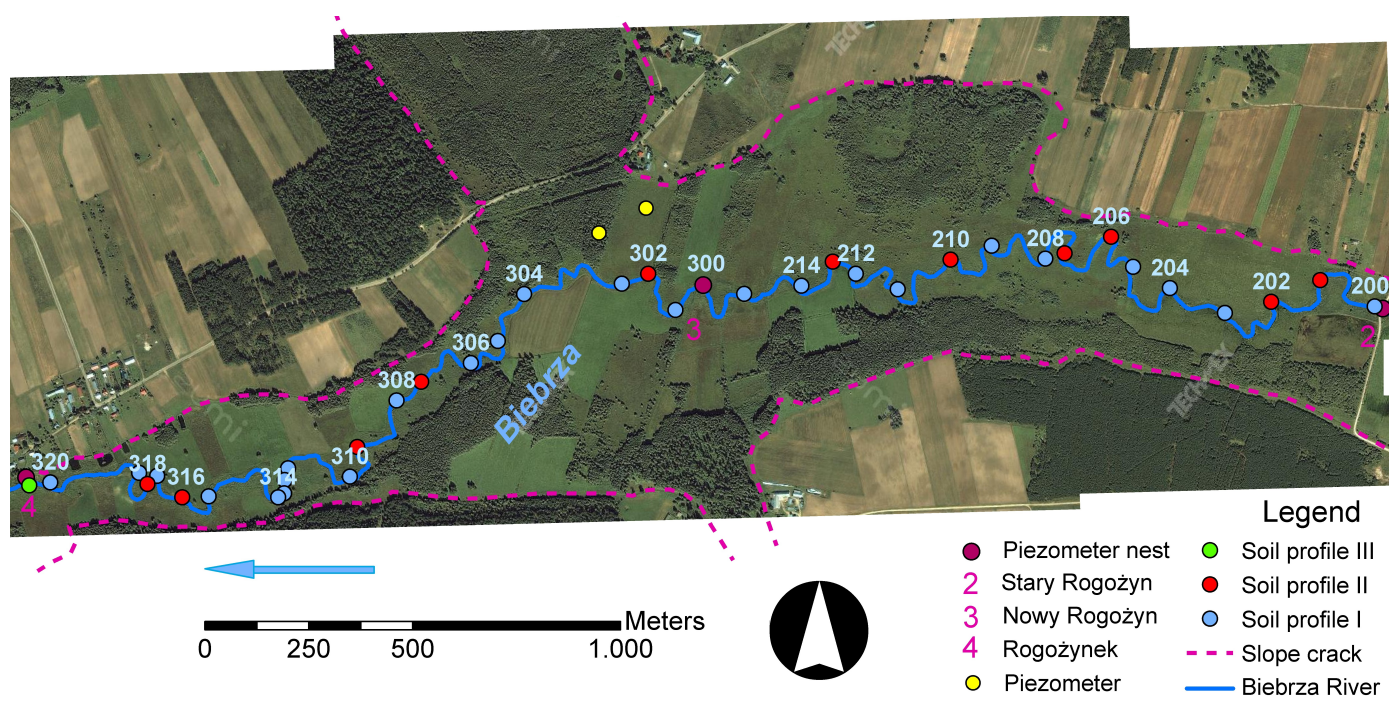

Fig. 3. Location of the 38 points (blue, red and green points) of the T-Stick measurements along the Biebrza River. The purple dots indicate the location of piezometer nests. The dashed line indicates the maximum extent of the alluvium or floodplain (i.e. the slope crack between valley wall and valley floor); a tributary is entering the alluvium from the south, in the north the alluvium extents into a paleochannel of the Biebrza River. On the right side of the alluvial plain, two piezometer nests are indicated. Orthophotomap source: www.zumi.pl.

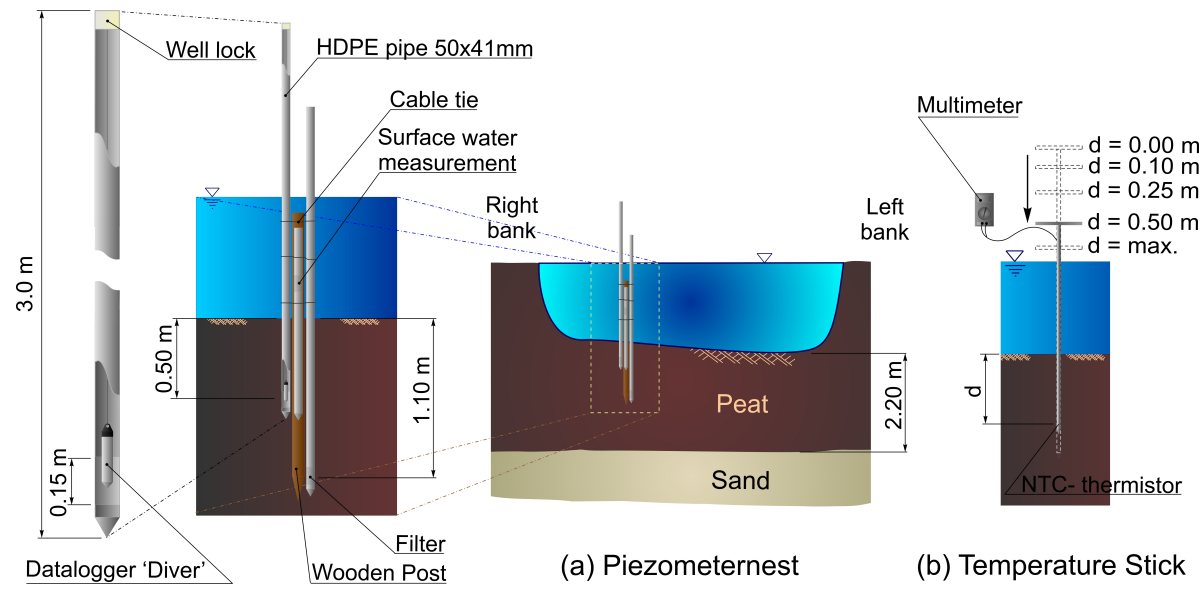

Fig. 4. (a) Setup for measuring temperature profiles and hydraulic head in the Biebrza River with piezometer nests equipped with data loggers, e.g. piezometer nest No. 2. (b) Scheme for measuring temperature profiles in the riverbed with the T-stick instrument.

the thermal method (Anderson, 2005; Kalbus et al., 2006; Constantz, 2008).

\subsection{Measurement techniques}

\subsubsection{Temperature stick}

We established 38 measurement points (Fig. 3), designated as points 200-300 between the villages of Stary Rogożyn (Fig. 3, No. 2), and Nowy Rogożyn (Fig. 3, No. 3) and points 300-400 between Nowy Rogożyn and Rogożynek (Fig. 3, No. 4), to gather temperature profiles of the riverbed. Field measurement campaigns of 2 consecutive days were performed by examining points $400-301$ on the first and
300-200 on the second day. The measurements were executed on 12-13 October, 17-18 November 2007, 5-6 March and 15-16 June 2008 with the so-called T-stick (Fig. 4b) instrument (Anibas et al., 2009, 2011). Additionally, several points were measured on 10 November and 8 December 2007. Using a Topcon GMS-2 GPS receiver with EGNOS differential correction, a relocation of the measurement points was possible with an accuracy of $1 \mathrm{~m}$. The measured temperature profiles consisted of measurements at the groundwater-surface water interface (i.e. $0.0 \mathrm{~m}$ ) and at 0.10 , 0.25 and $0.50 \mathrm{~m}$ depth in the riverbed (Fig. 4b). If possible, a measurement at the deepest reachable point was taken (on average this was $0.83 \mathrm{~m}$ ). 
Table 1. Physical and thermal properties of the soil profiles defined for the field site in the Upper Biebrza catchment.

\begin{tabular}{|c|c|c|c|c|c|}
\hline Soil* & Porosity $\Phi$ & $\begin{array}{l}\text { Specific heat capacity } \\
\quad \mathrm{c} \text { in } \mathrm{J} \mathrm{kg}^{-1} \mathrm{~K}^{-1}\end{array}$ & $\begin{array}{l}\text { Density } \rho \\
\text { in } \mathrm{kg} \mathrm{m}^{-3}\end{array}$ & $\begin{array}{l}\text { Thermal conductivity } \\
\lambda_{\mathrm{e}} \text { in } \mathrm{J} \mathrm{s}^{-1} \mathrm{~m}^{-1} \mathrm{~K}^{-1}\end{array}$ & Description \\
\hline Peat & 0.95 & 3900 & 1100 & 0.4 & Soil profile I and III \\
\hline Peat & 0.80 & 3300 & 1300 & 0.7 & Soil profile II \\
\hline Sand & 0.42 & 1300 & 2000 & 1.8 & Soil profile I, II and III \\
\hline
\end{tabular}

* completely saturated

Properties of the liquid phase (e.g. water): $c_{\mathrm{W}}, \rho_{\mathrm{W}}$ and $\lambda_{\mathrm{e}}$ are $4180 \mathrm{~J} \mathrm{~kg}^{-1} \mathrm{~K}^{-1}, 1000 \mathrm{~kg} \mathrm{~m}^{-3}$ and $0.6 \mathrm{~J} \mathrm{~s}^{-1} \mathrm{~m}^{-1} \mathrm{~K}^{-1}$, respectively.

\subsubsection{Piezometer nests}

At four locations (Figs. 2 and 3) along the river stretch, piezometer nests (Fig. 4a) were installed. Filters of $0.15 \mathrm{~m}$ length were placed at different depth in the riverbed (between 0.15 and $1.20 \mathrm{~m}$ ). They were equipped with temperature (StowAway ${ }^{\circledR}$ TidbiT ${ }^{\circledR}$, Onset Computer Corporation, Bourne, MA, USA) and/or Diver ${ }^{\circledR}$ temperature and hydraulic head data loggers (Schlumberger Water Services, Delft, The Netherlands) to continuously measure head and thermal gradients in the riverbed. The piezometer nests No. 2, 3 and 4 were furthermore measuring river water levels and temperatures. Rising and falling head slug tests were performed at the piezometer nests No. 2 and 3 .

\subsubsection{Seepage meters}

Four self-made seepage meters, metal and plastic barrels cut in half of 0.27 and $0.56 \mathrm{~m}$ in diameter were pushed into the sediment of the riverbed in a zone of around $50 \mathrm{~m}^{2}$ at Rogożynek (Fig. 3, No. 4). From 16-20 June 2008, nine measurements were performed by collecting during two hours seepage in plastic bags (volume 0.51 ). Pre-filled bags (0.11) were used to avoid anomalous short-term influx and to reduce the bag resistance (Murdoch and Kelly, 2003). Average values obtained from all four seepage meters were used.

\subsection{Thermal model}

In the surficial zone of the subsurface, the temperature shifts seasonally and diurnally, influenced by the heating and cooling of the land surface. During the summer months the groundwater temperature is generally cooler than stream temperature, whereas in winter it is generally the opposite. As groundwater flows according to hydraulic gradients, hence heat is solely transported by advection and conduction through the system influencing the temperature distribution in the porous media. Nowadays, temperature can be measured rapidly as sensors are technically simple, cheap, widely available and they can be handled easily.

Based on Stallman (1965) and Lapham (1989), the onedimensional, vertical, anisothermal transport of liquid and heat through homogeneous, porous media is formulated as:

$\lambda_{\mathrm{e}} \frac{\partial^{2} T}{\partial z^{2}}-q_{z} c_{\mathrm{w}} \rho_{\mathrm{W}} \frac{\partial T}{\partial z}=c \rho \frac{\partial T}{\partial t}$, where $\lambda_{e}$ is the effective thermal conductivity of the soilwater matrix in $\mathrm{J} \mathrm{s}^{-1} \mathrm{~m}^{-1} \mathrm{~K}^{-1}, \mathrm{~T}$ the temperature at point $z$ at time $t$ in ${ }^{\circ} \mathrm{C}, c_{\mathrm{W}}$ the specific heat capacity of the fluid in $\mathrm{J} \mathrm{kg}^{-1} \mathrm{~K}^{-1}, \rho_{\mathrm{W}}$ the density of the fluid in $\mathrm{kg} \mathrm{m}^{-3}, q_{z}$ the vertical component of the groundwater velocity in $\mathrm{m} \mathrm{s}^{-1}, c$ the specific heat capacity of the rock-fluid matrix in $\mathrm{J} \mathrm{kg}^{-1} \mathrm{~K}^{-1}$, and $\rho$ the wet-bulk density in $\mathrm{kg} \mathrm{m}^{-3}$. The first term of the left hand side of Eq. (1) represents the conductive and the second term the advective part of the heat transport. For convenience we express the vertical groundwater velocity in $\mathrm{mm} \mathrm{d}^{-1}$. A positive sign stands for water moving from the surface into the hyporheic zone (i.e. groundwater recharge or losing stream reach), and negative sign represents water moving from the hyporheic zone into the river (i.e. groundwater discharge or gaining stream reach).

The thermal method is an indirect method; the data measured in the field must be processed with a heat transport model in order to derive quantitative estimates of the flow velocity or flux. We apply inverse thermal modeling in which the calculation of vertical groundwater fluxes is achieved by solving Eq. (1) with transient boundary conditions. A vertical 1-D heat transport model STRIVE (Buis et al., 2008; Anibas et al., 2009) is used, based on the ecosystem modeling platform FEMME (Soetaert et al., 2002). The heat transport model obtains a best model fit by changing the value of the vertical groundwater velocity $\left(q_{z}\right)$ and minimizing the difference between the measured and simulated temperature distributions by user defined internal integration and fitting routines (Soetaert et al., 2002).

The STRIVE model for the Biebrza River is discretizised as a vertical, one-dimensional, heterogeneous, saturated soil column of $5.0 \mathrm{~m}$ length and composed of 100 layers. The spacing of the model layers follows a sinusoidal function, providing layer thicknesses of $0.001 \mathrm{~m}$ at the upper and lower boundary, while the thickness of the layers is increasing towards the center of the model domain to $0.08 \mathrm{~m}$. This setup was chosen to reduce discretization errors close to the groundwater-surface water interface.

A continuously measured surface water temperature data set (i.e. the solid line in Fig. 5) forms the upper boundary of the model domain. The lower boundary is defined as a constant temperature at $5.0 \mathrm{~m}$ depth (i.e. the dashed dotted line in Fig. 5), where it is assumed that no significant changes in temperature occur over time (Anibas et al., 2009). The 
temperature at the lower boundary is the average yearly value of a time series measured in a well close to the river in Rogozynek (i.e. point 4 in Fig. 3). One temperature profile measured with the T-stick, indicated by crosses, is used to initialize the model (i.e. the profiles of 10 or 11 October 2007), whereas the other three or four T-stick measurements in time are used to fit the modelled temperature distributions. With STRIVE's VODE (variable-coefficient ordinary differential equation) numerical integration routine, two hourly output values were simulated (Soetaert et al., 2004). The dotted lines in Fig. 5 show simulated temperatures of the respective depths of the T-stick measurements for the best model fit. The result of the simulation represents an integration of the flux over the given simulation period.

The described model setup was also applied with temperature time series from piezometers. The higher amount of data points used to fit the model allows reducing the simulation period and thus a higher temporal resolution.

To serve as upper model boundary, time series of surface water temperature were used. At the corresponding times, the STRIVE model requires this boundary to be identical with the uppermost measurement point (i.e. at $0.0 \mathrm{~m}$, Figs. $4 \mathrm{~b}$ and 5). Since there were only three different time series of surface water temperatures available for the entire river section, comprising of 38 measurement points, the time series were linearly interpolated to fit with the T-stick measurements.

According to pedological information derived from soil maps (Banaszuk, 2000) and information collected from drillings, vertically heterogeneous soil profiles were assigned to the model. At Rogożyn Nowy (Fig. 3, No. 3), a stratigraphy consisting of peat up to $2.2 \mathrm{~m}$ depth succeeded by a sandy soil layer (Fig. 4a) was found and used for all but one measurement point. At Rogożynek (Fig. 2, No. 4), additional information from the installation of the piezometer nests was available. A soil column consisting of a sandy surficial layer of $0.35 \mathrm{~m}$ thickness followed by a peat layer till $2.20 \mathrm{~m}$ depth and a sandy layer up to $5.00 \mathrm{~m}$ depth was therefore defined.

According to Stonestrom and Constantz (2003) and Anderson (2005), $\lambda_{\mathrm{e}}$ for saturated sands ranges usually between 1.4 and $2.2 \mathrm{~J} \mathrm{~s}^{-1} \mathrm{~m}^{-1} \mathrm{~K}^{-1}$, whereas for peat $\lambda_{\mathrm{e}}$ varies between 0.4 and $0.7 \mathrm{~J} \mathrm{~s}^{-1} \mathrm{~m}^{-1} \mathrm{~K}^{-1}$. As $\lambda_{\mathrm{e}}$ varies less than an order of magnitude for all soils found in riverbeds, $\lambda_{\mathrm{e}}$ values usually can be taken from the literature. This is a significant advantage compared to methods based on Darcy's law, as $\lambda_{\mathrm{e}}$ is equivalent to $K_{\mathrm{v}}$, the hydraulic conductivity, which varies over several orders of magnitudes (Chen, 2000). In order to handle the heterogeneities along the examined field location, three representative sets of physical-thermal parameters (Table 1) were estimated and assigned to the 38 measurement points. The thermal characteristics were determined based on physical properties of peat of the Biebrza River valley (Churski and Szuniewicz, 1994; Gnatowski et al., 2010), as well as the literature, including Farouki (1986), PetersLidard et al. (1998), Schwärzel et al. (2002) and Côté and

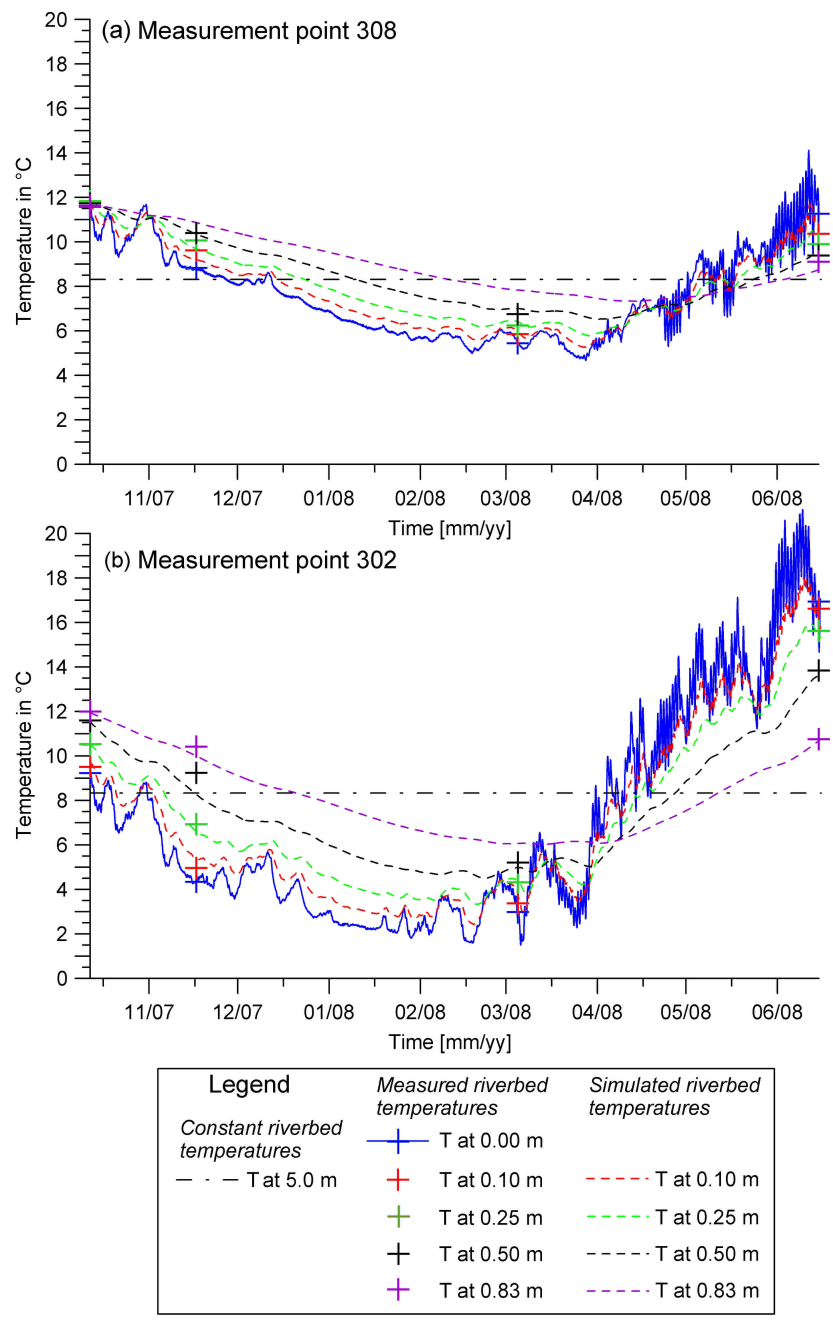

Fig. 5. Setup of the transient STRIVE model with results from measurement point 308 (a) and 302 (b). The riverbed temperature at $0.0 \mathrm{~m}$ depth serves as upper model boundary, a constant temperature at $5.0 \mathrm{~m}$ depth (the dashed-dotted line) as lower boundary. The crosses indicate the measurements with the T-stick instrument, whereas the dotted lines indicate the simulated temperatures at the respective points for the best model fit. (a) Soil type I, flux $=-6.5 \mathrm{mmd}^{-1}, \operatorname{RMSE}=0.41^{\circ} \mathrm{C}$; (b) Soil type II, flux $=-26.2 \mathrm{~mm} \mathrm{~d}^{-1}, \mathrm{RMSE}=0.46^{\circ} \mathrm{C}$.

Konrad (2005). Alternatively, uniform sets of parameters were used for simulations.

\subsection{Conceptual model}

In Fig. 6 we present a conceptual model for the estimation and understanding of groundwater-surface water interaction. Figure $6 \mathrm{a}$ shows the field measurements representing point estimates valid on a "local scale" not bigger than 1-10 m along and across the river reach. Riverbed bathymetry, the composition of the riverbed and the position of the measurement across the river are local factors which influence the 
(a) Local Scale
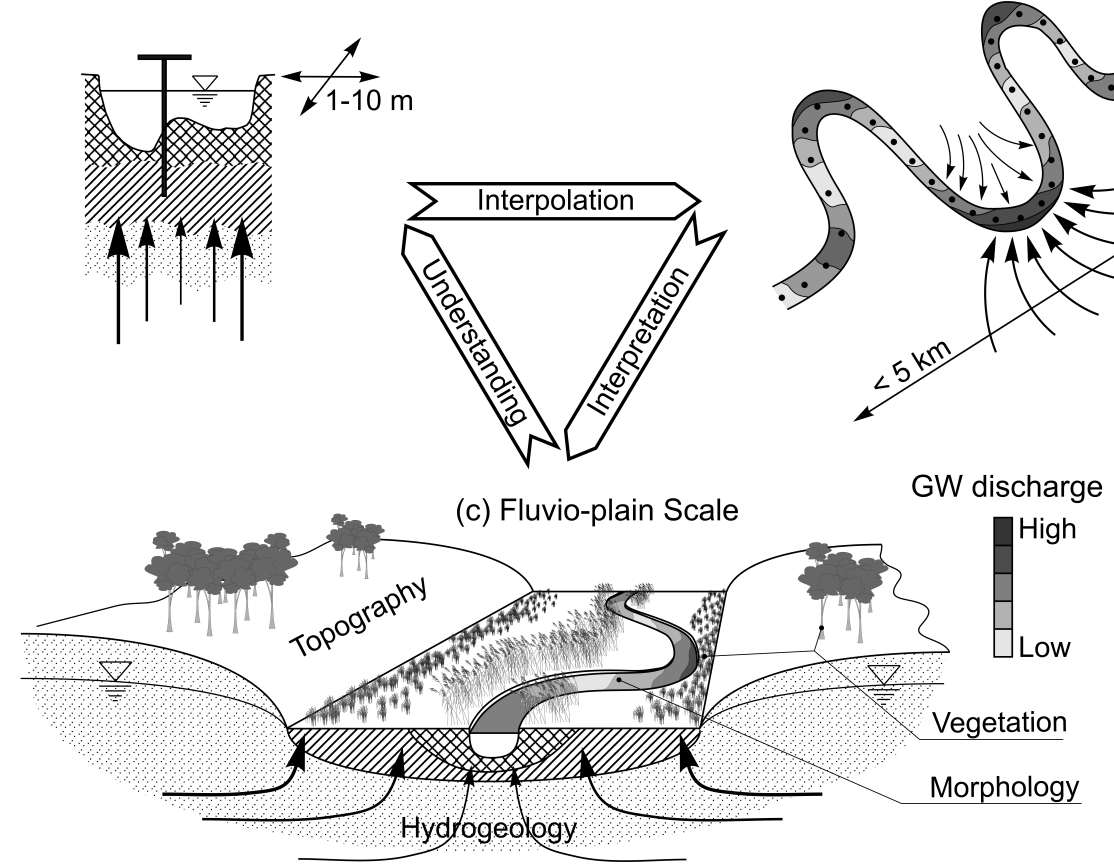

(b) Reach Scale

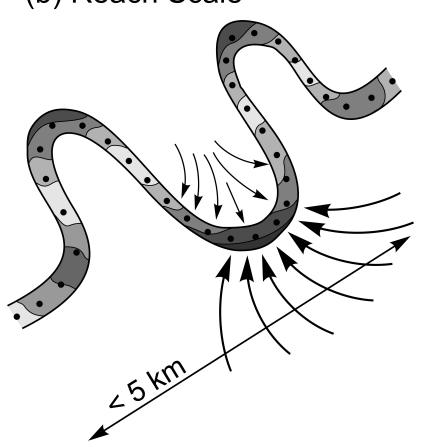

GW discharge

High

Fig. 6. Concept for the estimation and understanding of groundwater-surface water interaction. (a) Field measurements represent point estimates on a local scale: bathymetry, composition of the riverbed and the measurement position influence of the vertical flux estimate (e.g. local factors). (b) Interpolation reveals spatially distributed exchange patterns on a reach scale indicated in grey scales. For example, converging and diverging flow lines cause different exchange fluxes at convex and concave sides of meanders, respectively. (c) The quantity of exchange fluxes is dependent on morphology, topography, climate, vegetation and hydrogeology (e.g. regional factors). Hence, the interpretation of the groundwater-surface water interaction system is only possible when the system is analyzed at sub-basin or fluvio-plain scale. The improved understanding of the hydrological system is used to update, improve and control future investigation and modeling efforts on the local scale (a).

vertical flux estimates, indicated by the arrows of various size. Spatially distributed point estimates along and across a river reach can be interpolated on a "reach scale" Fig. 6b where spatial relationships and net exchange rates between the riverbed and river can be examined. The spatial distribution of exchange fluxes and their patterns are indicated in grey scales. For a meandering river reach, converging flow lines cause higher exchange fluxes at the convex banks of meanders, and lower exchange fluxes in the concave banks since the flow lines are diverging.

To interpret the derived flux pattern it is thus necessary to investigate the system in a wider context, the "subbasin" or "fluvio-plain" scale (Fig. 6c). The quantity of exchange fluxes also depends on regional factors like topography, climate, hydrogeology, hydromorphology and vegetation. These features are indicated in Fig. 6c by meanders, leading to varying distances between the river and the slope crack, the hydrogeological stratigraphy and vegetation patterns across the alluvium and the morainic plateau, respectively. The combination of all these features influences the groundwater-surface water interaction via the riverbed; interpretation of the interaction is only possible when the system is analyzed at sub-basin or fluvio-plain scale. A better understanding of the hydro-ecological functioning hence can be achieved when the obtained results are used to update future field work and modeling of the system.

\section{Results and discussion}

\subsection{Heterogeneity of the riverbed}

Figure 5 is representative for the range of temperatures measured and simulated along the examined reach of the Biebrza River. Exemplarily, the temperature profiles measured between 12 October 2007 and 16 June 2008 of two measurement points, 308 (Fig. 5a) and 302 (Fig. 5b), are shown together with corresponding surface water temperature time series. Since the measured temperatures are clearly different, it is obvious that strong temperature variations exist between the $38 \mathrm{~T}$-stick measurements along the examined river reach. On 15-16 June 2008, for example, maximal temperature differences of $7.9^{\circ} \mathrm{C}$ and $6.1^{\circ} \mathrm{C}$ were detected between the 38 measurement points at $0.0 \mathrm{~m}$ and $0.5 \mathrm{~m}$ depth, respectively. These spatial differences were consistent over time since the minimal differences measured on 5-6 March 2008 
showed still values of $4.2^{\circ} \mathrm{C}$ at $0.0 \mathrm{~m}$ depths and $2.6^{\circ} \mathrm{C}$ at $0.5 \mathrm{~m}$. Measured thermal gradients between 0.0 and $0.5 \mathrm{~m}$ had a range of $0.1^{\circ} \mathrm{C}$ to $5.8^{\circ} \mathrm{C}$, whereas the measurement campaign of 12-13 October 2007 showed the lowest gradients, with an average of $1.5^{\circ} \mathrm{C}$. The campaign of 17 18 November 2007 indicated the maximum gradients, with depths (i.e. $3.4^{\circ} \mathrm{C}$ ). The minima and maxima of the measured surface water temperature time series within the simulation period were 3.8 and $16.5^{\circ} \mathrm{C}$ for point No. 2 and -0.1 and $21.3^{\circ} \mathrm{C}$ for point No. 4 , respectively. The average surface water temperature of the winter season of 2007-2008 was 4.4 and $2.0^{\circ} \mathrm{C}$ for No. 2 and No. 4 , respectively.

Conant (2004) and Anibas et al. (2011) suggest that strong temperature differences of spatially distributed measurement points indicate an heterogeneous pattern of groundwatersurface water exchange. However, at the Biebrza River alongside the thermal pattern, strong spatial variations in physical consistency of the riverbeds peat soils were revealed. Therefore, we assume that the variation in temperature indicates, beside differences in groundwater fluxes, also the spatial heterogeneity of soil physical properties between the different measurement points. A classification was established by a simple manual and visual examination point for point, assessing color, consistency and resistance to penetration. The procedure was then repeated at every measurement campaign. Two peat types were distinguished, one showing a soft, loose structure whereas the other was fairly compact. Together with the underlying sand, they are designated as "soil profile I" and "soil profile II", respectively. At point 400 , where the river approaches the morainic upland, the riverbed becomes sandy and a more heterogeneous stratigraphy is present, i.e. "soil profile III". The peat was assigned with similar physical values as soil profile I. A few measured profiles showed intermediate characteristics of soil profiles I and II; they were either classified according to the one which showed the best model fit, or average values of simulated fluxes were used for further analysis. For the different peat soils parameter sets were assumed as summarized in Table 1.

Soil profile I is characterized by a dark, black colour and a muddy consistency. Often no clear interface between surface water and riverbed is present; in the region up to around $0.10-0.15 \mathrm{~m}$ depth, the peat behaves like a suspension with a gradually decreasing porosity. Since the interface is not well determined, it is difficult to define the absolute position of the temperature measurement. The pedological map of the Biebrza National Park indicates that this soil is predominantly composed of "reed peat" (Banaszuk, 2000). Temperature measurements of soil profile I indicate highly dampened temperatures with depth and flat thermal gradients, as can be seen from measurement point 308 (Fig. 5a). In contrast to sites with sandy soils (Schmidt et al., 2007; Anibas et al., 2011), where a similar thermal pattern indicates high discharge fluxes, peat soils must be assigned with low thermal conductivity, high heat capacity and porosity values to get an acceptable model fit. Consequently, by applying the respective parameter values of Table 1, these locations show quite low flux estimates.

In contradiction to soil profile I, profile II is characterized by a stable, compact consistence of the riverbed with a clear interface between the riverbed and the surface water. According to the pedological map (Banaszuk, 2000), this soil type is associated with "moss-sedge peat" or "alder swamp peat". The temperature variations over time and depth are, compared to soil profile I, much stronger (Fig. 5b), indicating different fluxes and different soil properties. For soil profile II, a higher thermal conductivity and a lower heat capacity have to be applied. The final values (Table 1) were established by manual calibration runs of the transient thermal model in STRIVE, leading in general to higher flux estimates than for soil profile I. This difference is underlined by statistical tests, Kolmogorov-Smirnow and Mann-Whitney U tests (population size $N=38$; level of significance $p=0.05$ ).

The stratigraphy and physical properties of the riverbed influence the estimated fluxes when the soil parameters change relatively close to the sediment-water interface. Test runs with STRIVE showed that the influence of the sand layer at a depth of $2.2 \mathrm{~m}$ (i.e. below the peat) is limited since the exchange of thermal energy at this depth is relatively low.

Viewed in the broader context (i.e. fluvio-plain scale; Fig. 3), the fluvial plain in the upper part of the investigated section has a constant width of around $370 \mathrm{~m}$. From point 208 till point 303 it is widening up to a width of $780 \mathrm{~m}$. Between point 304 and 310 the alluvium steeply narrows again and the width remains around $290 \mathrm{~m}$ until the lower end of the section. Soil profile I is on average farther away from the right slope crack of the valley and is found closer at the left side, whereas for soil profile II this is the opposite. The pedological map (Banaszuk, 2000) also shows different soil composition in the center of the floodplain and towards the left side of the alluvium. This finding, however, could not be supported with the Kolmogorov-Smirnow and a Mann-Whitney $\mathrm{U}$ tests $(N=34, p=0.05)$. Slug tests performed at piezometers across the right side of the alluvium (Fig. 3) indicate a decrease in horizontal hydraulic conductivity $K_{\mathrm{h}}$ between the slope crack and the river course. The values decrease slightly from $0.65 \mathrm{~m} \mathrm{~d}^{-1}$ to $0.58 \mathrm{~m} \mathrm{~d}^{-1}$ across the alluvium towards the river, whereas in the riverbed the value drops to $0.10 \mathrm{~m} \mathrm{~d}^{-1}$.

\subsection{Spatial variation}

Figure 7 shows the results of the STRIVE simulations using the parameters of Table 1 as bar graph for the 38 measurement points. The colours of the bars indicate the different soil profiles I, II and III in blue, red and green, respectively, similar to the dots in Fig. 3. The maximum flux is observed at point 210 , with an exfiltration of $-37 \mathrm{~mm} \mathrm{~d}^{-1}$ and the minimum exfiltration rate is $-6.3 \mathrm{~mm} \mathrm{~d}^{-1}$ at point 311 . Point 215 shows an infiltration rate of $4.8 \mathrm{~mm} \mathrm{~d}^{-1}$. Points 209 and 320 , for example, belong to soil profile I and show high discharge 


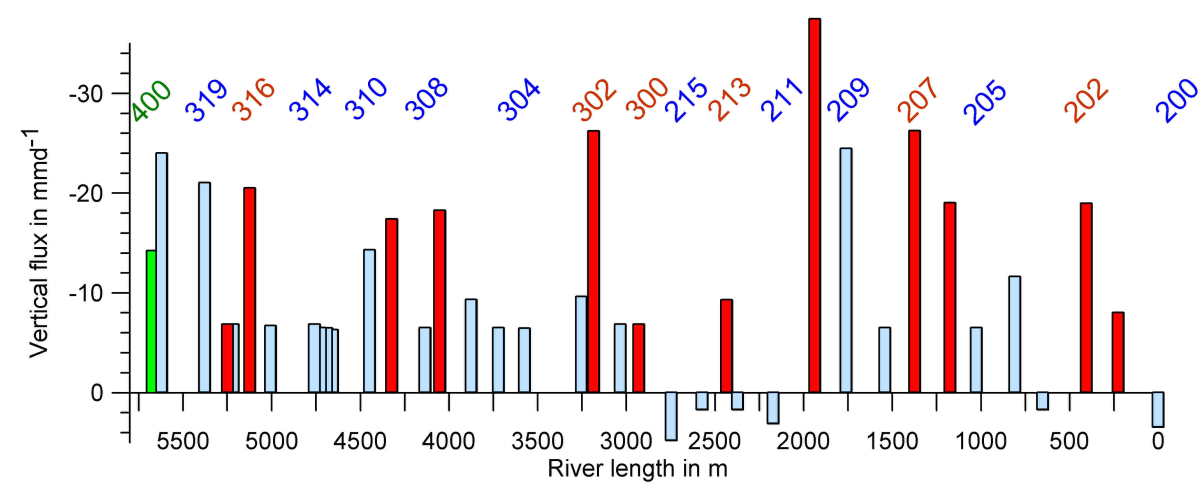

Fig. 7. Results of transient simulations per measurement point with STRIVE. The bars indicate the integrated fluxes per measurement point between 11 October 2007 and 17 June 2008; the colours of the bars indicate soil profiles I, II and III, respectively, in blue, red and green.

values, whereas points 205 and 300, which are soil profile II, show relatively low discharge values. These results contradict the average differences found between the flux estimates of soil profile I and II, indicating that the spatial exchange pattern does not only depend on the composition of the riverbed. Hence, the fluxes obtained on a local scale are also influenced by regional factors. An average root mean square error (RMSE) between the measured and the simulated temperatures of $0.44^{\circ} \mathrm{C}$ has been obtained. The RMSE for soil profile I is with $0.39^{\circ} \mathrm{C}$ lower than the RMSE of soil profile II with $0.50^{\circ} \mathrm{C}$.

Compared with a thermal steady state analysis as presented by Anibas et al. (2011), using the measurements of 5-6 March 2008 shows a significant correlation between the spatial pattern of the steady-state and the transient simulations (Spearman rank $R$ and Gamma tests; $N=38, p=0.05$ ). In the case where uniform thermal and physical properties are assigned for all measurement points, a rather uniform distribution of flux estimates is obtained along the reach. For this analysis the model fit was all but satisfactory; RMSE values of more than $1.5^{\circ} \mathrm{C}$ were common. The analysis indicates that the estimation and classification of thermal properties of peat soils on a local scale is important to be able to correctly observe and interpret spatial relationships and heterogeneities on the reach and fluvio-plain scale.

From Fig. 7 it is obvious that the flux estimates along the river are fairly heterogeneous and in first instance no clear patterns are visible. We used a multilog radial bases function (Surfer 8.04, Golden Software, 2003) for the spatial interpolation of the determined point estimates (Fig. 7), where the parameter $R^{2}$ was set as 1800 . This leads, despite the limited amount of measurement points, to a continous distribution of exchange fluxes along the river reach (Fig. 8b). An anisotropy ratio of 2.5 and an angle of $20^{\circ}$ were used to represent the orientation of the river course. Figure $8 \mathrm{~b}$ shows the range of the interpolated flux estimates, with a maximum exfiltration of $-29.4 \mathrm{~mm} \mathrm{~d}^{-1}$ and a maximum infiltration of $4.7 \mathrm{~mm} \mathrm{~d}^{-1}$. An average flux of $-10.4 \mathrm{~mm} \mathrm{~d}^{-1}$ was calculated, leading to a (vertical) net exchange rate of $-5.441 \mathrm{~s}^{-1}$ along the entire river section of $5670 \mathrm{~m}$. Given an average discharge of $0.31 \mathrm{~m}^{3} \mathrm{~s}^{-1}$, this is $1.8 \%$ of the average surface water discharge at point No. 4. The Biebzra River hence gains $0.32 \%$ of the average discharge at the outlet of the examined section per $\mathrm{km}$ of river. A study of the Belgian Aa River (Anibas et al., 2011) shows a respective value $0.42 \%$ per $\mathrm{km}$. Both rivers are low land rivers but the difference in size, and probably more importantly the different hydrogeology, strongly determine these differences. At the investigated sites, the Aa River is considerably bigger then the Biebrza River and has a sandy riverbed.

Notice that some parts of the river course show infiltrating and others discharging conditions (Fig. 8a). The section between the measurement points 301-211 is slightly infiltrating, whereas just further upstream, between the points 210206, the highest exfiltration rates are estimated. A total $91.4 \%$ of the interpolated river surface shows exfiltrating characteristics, whereas $8.6 \%$ indicates recharge. The exfiltrating zone shows a net flux of $-5.541 \mathrm{~s}^{-1}$, whereas for the infiltrating zone a flux of $0.101 \mathrm{~s}^{-1}$ is estimated. The section halfway along the examined river section and locations relatively far from the slope crack show the lowest flux values.

Since the total river length from the source to measurement point No. 4 is just about $15 \mathrm{~km}$ (Fig. 2), the estimated net exchange fluxes alone cannot explain the amount of surface water discharge of the river. A lateral flow component has to be responsible for this difference, which supports the hypotheses of van Loon et al. (2009). They suggest the occurrence of groundwater discharge at the slope crack between valley wall and floor and a shallow permeable zone within the alluvium, which allow shallow lateral flow towards the river. In the center of the alluvium it is expected that the groundwater discharge is lower than in the vicinity of the slope crack (van Loon et al., 2009).

Figure $8 \mathrm{a}$ shows measurements of surface water discharge at 7 positions along the river section between No. 2 and 4 (De Doncker et al., 2009). Significant changes in discharge along the section are indicated. The discharge at the most downstream point (i.e. G), however, is in the same range as at the 

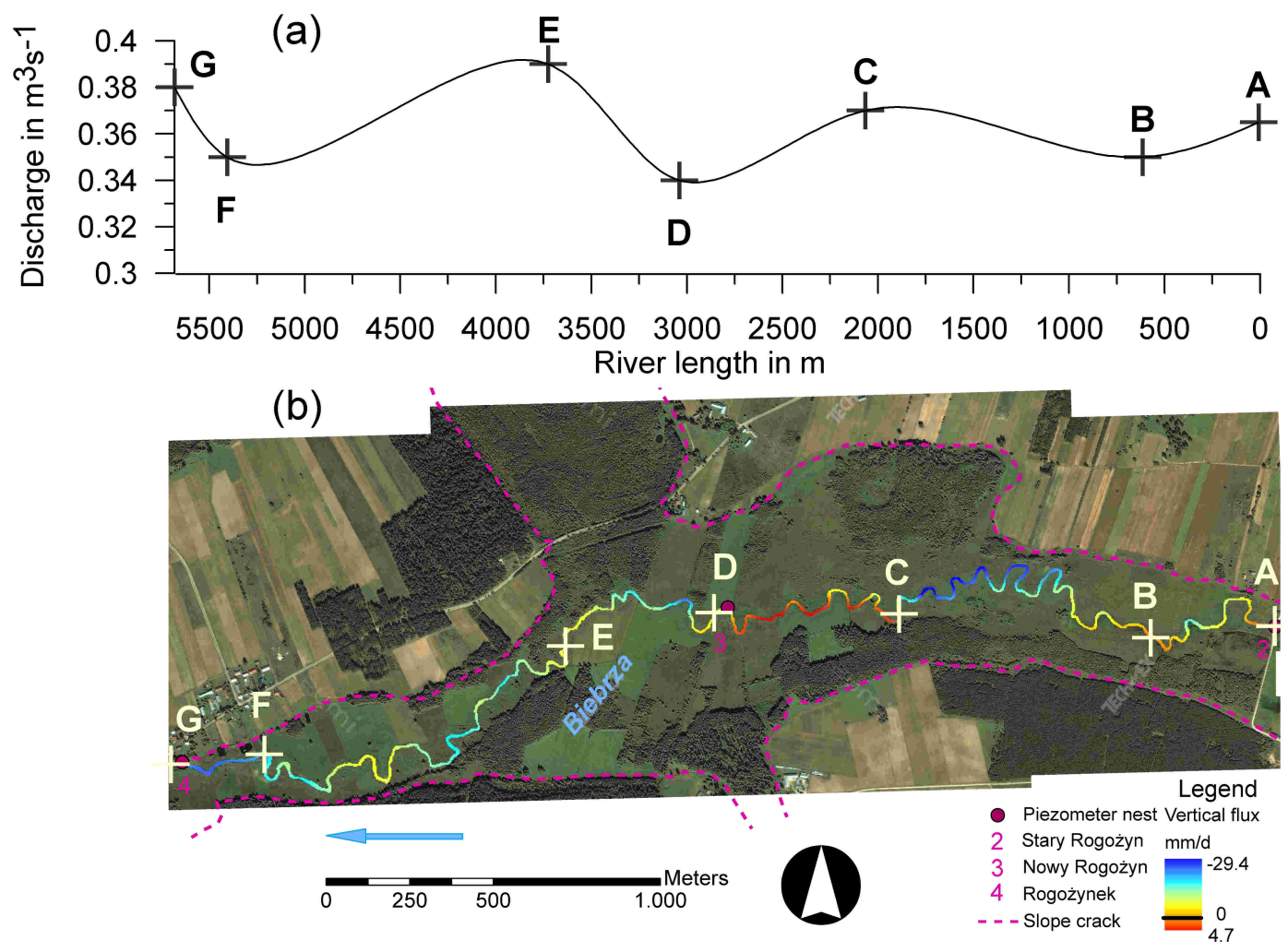

Fig. 8. (a) Surface water discharge measurements A-G along the river section according to De Doncker et al. (2009). (b) Spatial interpolation of the point estimates of the transient simulation on a reach scale indicated as coloured band. The location of the surface water measurements A-G are indicated by crosses. Orthophotomap source: www.zumi.pl.

upstream point (i.e. A). The changes in discharge quantitatively are too strong to be explained by the variations of vertical fluxes obtained by the thermal analysis. Again, in line with van Loon et al. (2009), a lateral contribution of groundwater flow to the river can account for the differences. However, the interpolated flux (Fig. 8b) shows a comparable spatial trend along the river stretch: the strong discharge zone between points $210-206$, the slight recharge zone between points 301-211 and the increasing discharge between 319 and 400 are well reproduced (Fig. 8). Because of the growth of macrophytes and a varying cross-section, estimates of surface water discharge are difficult to perform and their results may therefore have a considerable error.

Statistical tests have been performed on the reach scale using the point estimates of Fig. 7. Since the flux estimates are not normally distributed (supported by Lilliefors and Shapiro-Wilk tests, $N=38$ ), nonparametric statistical tests have been applied. Although $N$ is relatively small compared to other works, e.g. Anibas et al. (2011), some relationships between the magnitude of vertical flux values and morphologic features can be examined.

A correlation (Spearman Rank Order Correlations, Gamma correlations and Kendall Tau Correlations tests, $N=38 ; p=0.05)$ is found for the flux rates of the measurement points versus the distance of each point to the slope crack (indicated as dashed lines in Figs. 3 and $8 b$ ). Along the right side of the river section, high fluxes correlate with short distances, whereas such a correlation for the left side of the river is not significant until $p$ is increased to 0.10 . Higher fluxes are detected closer to the slope crack where predominantly soil type II is abundant (i.e. the right side of the alluvium), indicating changing flux rates across the flood plane. Results from the groundwater model of van Loon et al. (2009) show high groundwater discharges along the slope crack, which supports the relationship between measurement location within the alluvial plain and magnitude of flux.

We classified the flux estimates according to their position along the river reach to investigate the relationship between the morphologic features and the calculated fluxes. In general the morphology of the river consists of straight sections and meanders. Measurement points located on the convex edges of meanders (i.e. cut banks), and where the river flow is straight, parallel or perpendicular with respect to the general orientation of the river valley, are grouped and examined with a Mann-Whitney $\mathrm{U}$ test $(N=38, p=0.05)$. The test indicated that fluxes on the edges of meanders are significantly higher than at other positions. By adopting the Mann-Whitney statistical test $(N=23 ; p=0.05)$, differences 


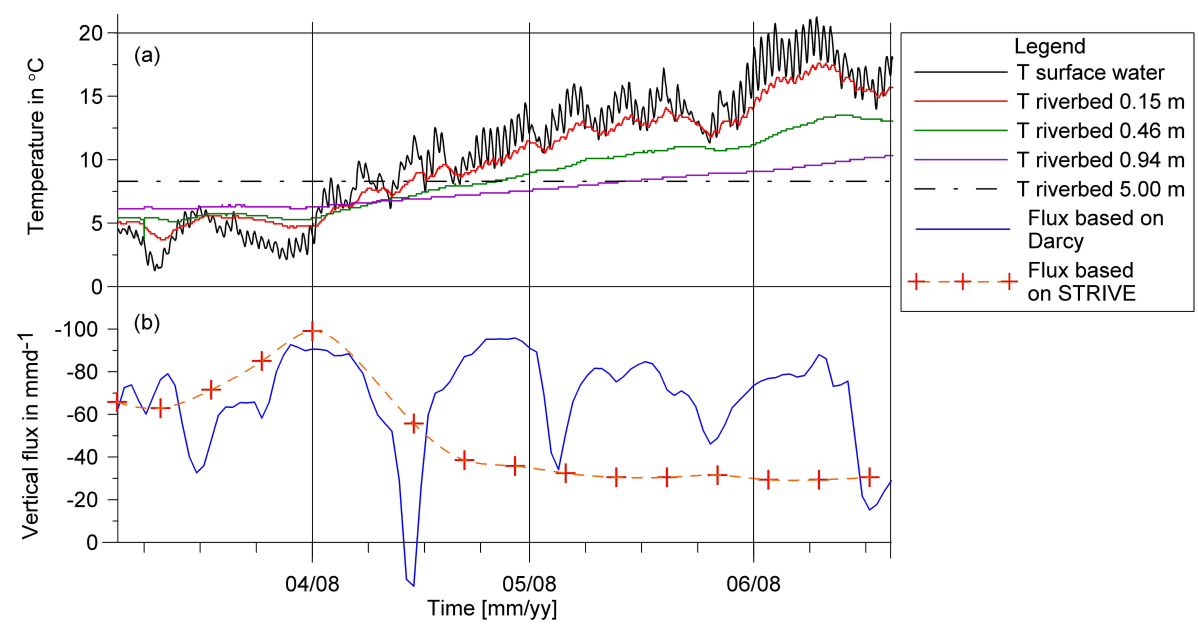

Fig. 9. (a) Surface water temperature and measured groundwater temperatures at different depths in piezometer nests No. 4. (b) Corresponding estimated fluxes using weekly transient thermal simulations with STRIVE as well as daily averaged fluxes based on Darcy calculations.

between other features, like sections of parallel and perpendicular flow with respect to the general flow direction, could not be revealed. The high fluxes on the outer edges of meanders can be explained by the combined effect of the (shorter) distance to the slope crack between morainic upland and alluvial plain and the convergence of groundwater flow lines towards them. In general, points closer to the left side of the alluvium show low fluxes, which can be an indication that the groundwater discharge from the right side of the alluvium is stronger than from the left side. This is probably caused by differing riverbed compositions since soil type I and II are indicated closer to the left and the right side of the alluvium, respectively. The hydromorphology on the reach scale, however, cannot completely explain the occuring difference in fluxes. Regional factors factors like topography and hydrogeology, which become visible at the bigger fluvio-plain scale, must be responsible for the variability in fluxes. Hence, for the correct interpretation of results gained on the reach scale, the sub-basin or fluvio-plain scale has to be taken into account.

\subsection{Temporal variation}

STRIVE can also simulate temporal changes in groundwater and surface water exchange. Analysis performed for Dujardin et al. (2011) indicated that transient simulations with a period of one week are feasible using the presented model setup if sufficient (i.e. continuously measured) data are available to fit the model. Figure 9a shows temperature data of piezometers No. 4 for the period 3 March to 20 June 2008. In Fig. 9b, flux results based on hydraulic gradient data are compared with transient simulations of weekly duration from STRIVE. The global trend of groundwatersurface water interaction is well reproduced by the heat transport model. The model, however, fails to reproduce sharp peaks of exchange flows. Since the measurement accuracy of the used thermal sensors is less than $0.3^{\circ} \mathrm{C}$, a sufficiently high temperature gradient and time is needed to detect temperature changes with depth to get a reliable flux estimate over the given simulation period. This and initialization errors limit the temporal resolution of STRIVE to 1-2 weeks (Dujardin et al., 2011).

Flux estimates with a higher temporal resolution, however, can be generated by connecting the heat transport model with hydraulic head data from the piezometer nests. Values for vertical hydraulic conductivity $K_{\mathrm{v}}$ were estimated for periods with stable head gradients by calculating respective flux rates with STRIVE using transient simulations and by applying Darcy's law (Lapham, 1989). Using data from piezometer nest No. 2, a $K_{\mathrm{v}}$ of $0.22 \mathrm{~m} \mathrm{~d}^{-1}$ was estimated. $K_{\mathrm{V}}$ of piezometer nests No. 3 and 4 are $0.81 \mathrm{~m} \mathrm{~d}^{-1}$ and $0.05 \mathrm{~m} \mathrm{~d}^{-1}$, respectively (Table 2). Table 2 also shows the estimates of the horizontal conductivity $K_{\mathrm{h}}$ derived from falling and rising head slug tests in the respective piezometer nests No. 2 and 3. The anisotropy $K_{\mathrm{h}} / K_{\mathrm{V}}$ ranges from 1.2 at No. 2 to 0.1 at No. 3, which is, despite its range, in agreement with literature values (Chen, 2000).

The estimated $K_{\mathrm{v}}$ values were then applied on time series data of hydraulic gradients measured in the piezometers to calculate hourly values of exchange flux. Figure 10 shows the results of the analysis between 13 September 2007 and 20 June 2008. For Piezometer nests No. 2, a continuous dataset is available showing an average infiltration of $4.8 \mathrm{~mm} \mathrm{~d}^{-1}$. Piezometer No. 3 shows an average exfiltration of $-25.6 \mathrm{~mm} \mathrm{~d}^{-1}$ in the period of 13 September 2007 till 8 December 2007, whereas No. 4 shows an average value of $-78.9 \mathrm{~mm} \mathrm{~d}^{-1}$ from 4 March 2008 till 20 June 2008. The corresponding analysis of the points 200, 300 and 400 shows exchange fluxes of a lower magnitude (Fig. 7) but of a comparable distribution, respectively, of low infiltration, exfiltration and strong exfiltration. The highest determined fluxes at 
Table 2. Estimated vertical hydraulic conductivity $K_{\mathrm{V}}$ using thermal and hydraulic head data.

\begin{tabular}{|c|c|c|c|c|c|c|c|}
\hline $\begin{array}{l}\text { Piezometer } \\
\text { nest No. }\end{array}$ & $\begin{array}{l}\text { Simulation } \\
\text { period: } \\
\text { begin } \\
{[\mathrm{dd} / \mathrm{mm} / \mathrm{yy}]}\end{array}$ & $\begin{array}{l}\text { Simulation } \\
\text { period: } \\
\text { end } \\
{[\mathrm{dd} / \mathrm{mm} / \mathrm{yy}]}\end{array}$ & $\begin{array}{r}\text { Vertical } \\
\text { flux }^{1} v_{z} \\
\text { in } \mathrm{mm} \mathrm{d}^{-1}\end{array}$ & $\begin{array}{r}\text { Difference } \\
\text { in head } \\
\Delta h \text { in cm }\end{array}$ & $\begin{array}{c}\text { Vertical } \\
\text { hydraulic } \\
\text { conductivity } \\
K_{\mathrm{V}} \text { in } \mathrm{md} \mathrm{d}^{-1}\end{array}$ & $\begin{array}{c}\text { Horizontal } \\
\text { hydraulic } \\
\text { conductivity } \\
K_{\mathrm{h}} \text { in } \mathrm{m} \mathrm{d}^{-1}\end{array}$ & $\begin{array}{c}\text { Anisotropy } \\
\text { ratio } \\
K_{\mathrm{h}} / K_{\mathrm{V}}\end{array}$ \\
\hline 1 & 6 Aug 2007 & 28 Aug 2007 & -24.5 & - & - & - & - \\
\hline 2 & 18 Jan 2008 & 4 Mar 2008 & 3.5 & 3 & 0.22 & 0.26 & 1.2 \\
\hline 2 & 8 Feb 2008 & 22 May 2008 & -6.5 & 2 & 0.22 & 0.26 & 1.2 \\
\hline 3 & 6 Aug 2007 & 28 Aug 2007 & -36.2 & -4 & 0.81 & 0.10 & 0.1 \\
\hline 3 & 9 Mar 2008 & 28 Apr 2008 & -20.4 & -3 & 0.81 & 0.10 & 0.1 \\
\hline $4 \mathrm{~A}$ & 6 Aug 2007 & 28 Aug 2007 & -21.9 & -36 & 0.05 & - & - \\
\hline $4 B$ & 6 Aug 2007 & 28 Aug 2007 & -38.4 & -36 & 0.05 & - & - \\
\hline $4 B$ & 14 Apr 2008 & 15 Jun 2008 & -29.8 & -29 & 0.05 & - & - \\
\hline
\end{tabular}

${ }^{1}$ using transient STRIVE simulations; ${ }^{2}$ from piezometer nests; ${ }^{3}$ from falling and rising head slug tests.

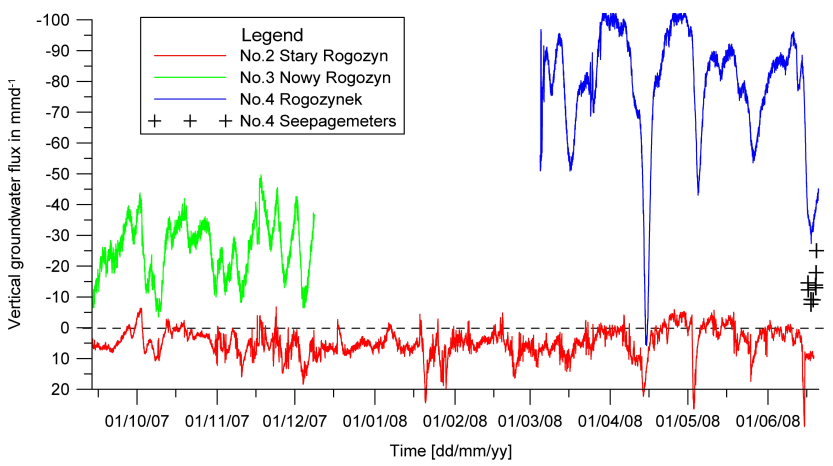

Fig. 10. Temporal distribution of the GSI in the riverbed of the Biebrza River based on time series of hydraulic head and hydraulic conductivity values derived with STRIVE.

the location showing the lowest $K_{\mathrm{v}}$ indicates that the quantity of the fluxes along the reach is primarily determined by differing hydraulic head gradients rather than by differences in hydraulic conductivity. Point No. 4 also shows a high temporal variability of exchange fluxes. The point is located close the slope crack and has relatively high fluxes, highlighting the influence of the exfiltration zone at the interface (van Loon et al., 2009). Long periods of relative stable flow conditions are interrupted by peaks of river discharge where the magnitude of the exchange fluxes alters rapidly and can reverse the flow direction from exfiltrating to infiltrating conditions; exfiltration, however, is dominating. Infiltration rates of $5.8 \mathrm{~mm} \mathrm{~d}^{-1}$ were calculated, while during exfiltrating conditions flux values reach $-104.3 \mathrm{~mm} \mathrm{~d}^{-1}$ at piezometer No. 4.

Piezometer No. 3 is located far from the slope crack in the middle of the alluvial plain and shows, in comparison to No. 4, lower values of exchange fluxes and less fluctuation; minima and maxima of -3.0 and $-49.7 \mathrm{~mm} \mathrm{~d}^{-1}$ were determined. Piezometer nest No. 2, with respective values of 32.1 and $-6.8 \mathrm{~mm} \mathrm{~d}^{-1}$, shows, compared to piezometer nests
No. 3 and 4, predominantly an infiltration of surface water into the hyporheic zone. Piezometer nest No. 2, in comparison with No. 4, is located farther away from the slope crack and the valley floor is wider, explaining the differences in exchange fluxes and the peat resembles soil profile I. Piezometers, however, are difficult to place and to maintain, especially when they are placed directly in the riverbed. A STRIVE simulation of temperature data from piezometer No. 1, where no useful head data sets could be retrieved, shows that the flux is within the range of the results of the other piezometers (Table 2). Correct measurements of head gradients are, in comparison with temperature measurements more challenging.

\subsection{Validation}

By calculating $K_{\mathrm{v}}$ using both STRIVE and head gradients, the two methods were not applied independent from each other. Therefore, we performed seepage meter measurements in Rogożynek (Fig. 3, No. 4) to have an independent validation of our previously presented results. The magnitude of the seepage meter fluxes follow the temporal pattern of the time series of fluxes based on head gradients measurements (Fig. 10). For the examined period between 16-20 June 2008, the head based fluxes, however, yielded a higher flux of $-36 \mathrm{~mm} \mathrm{~d}^{-1}$, whereas the seepage meters indicated an average flux of $-14 \mathrm{~mm} \mathrm{~d}^{-1}$. A transient thermal simulation of temperature profiles collected close to the placed seepage meters using STRIVE resulted in a flux of $-10 \mathrm{~mm} \mathrm{~d}^{-1}$. Since a vertical heterogeneity in flux rates is possible (Chou, 2009), these differences can be attributed to the different assumptions, boundary conditions and uncertainties of the methods and are regarded as acceptable in the scope of the study. The thermal model, for example, integrates the exchange fluxes over a vertical domain of $5.0 \mathrm{~m}$ assuming a constant flux rate at depth, whereas the head and seepage meter measurements use a domain of less than $1 \mathrm{~m}$. Hence, 
a perfect agreement on the determined fluxes between these methods is unlikely.

\section{Conclusions}

A hierarchical approach to quantify and interpret groundwater-surface water interaction in space and time was presented by applying a combination of different field methods along a section of the upper catchment of the Biebrza River in Poland. Temperature profiles taken with the T-stick instrument and time series of hydraulic head and temperature gradients measured in piezometer nests allowed the detection of spatial and temporal variation of groundwater-surface water exchange in the riverbed. Seepage meter measurements and slug tests were used for the validation of the model results. With the combination of different field methods limitations of a single method can be overcome, which is increasing the credibility of the obtained results.

The heterogeneity and complexity of groundwater-surface water exchange processes underline the importance of selecting the appropriate scale for monitoring and interpretation (Vaughan et al., 2009). As shown in a conceptional model (Fig. 6), we suggest a hierarchical approach to interpret and understand the determining factors of these exchange. Point estimates of the exchange fluxes are representative on a local scale, where the local factors (e.g. the composition of the riverbed, riverbed bathymetry, elevation and position across the riverbed) have to be taken into account. The variability along the river course, though, cannot be explained by the local factors alone. Spatial patterns become visible when the results are analyzed on a reach scale. There, "hot spots" of high or low exchange fluxes and zones of ex- and infiltration and relations between the exchange fluxes and morphologic and topographic features can be identified. To understand the underlying mechanisms of interaction, an even wider scope at the fluvio-plain or sub basin scale (determined by the regional factors like topography, morphology, climate, vegetation and hydrogeology) is necessary. It is thus indispensable to interpret fluxes determined on a local scale in a wider perspective. The groundwater-surface water exchange pattern at the discussed scales might, however, be subject to specific temporal and spatial variations.

Heat transport modeling was performed using spatially distributed measurements and time series from piezometer nests; an acceptable agreement between the two models setups was found. The thermal method also showed a good agreement with head based flux estimates and with seepage meter measurements. As it was observed in Sect. 4.4, it is possible that the vertical fluxes are non-steady over depth (Chou, 2009). With the presented setup a vertical variabilty of fluxes cannot be examined, however.

In an area dominated by wetlands and peat soils, the range of measured temperatures is very high even during a single measurement campaign. In opposition to what is valid for sandy riverbeds, we conclude that large variations in measured temperatures and thermal gradients are not only caused by differing fluxes but also by changing physical properties in the riverbed. These differences are controlled by varying soil properties (i.e. local factors) resulting in a scattered pattern of estimated flux rates at a local scale (Figs. 5a and 7). The soil properties are heterogeneous with depth and also vary along the river course and across the flood plain. This finding results in the necessity to classify the model parameters. We defined stratified soil profiles and introduced different sets of physical properties for the different measurement points (Table 1). However, this study probably does not cover the complete physical and hydrological heterogeneity of the river section, since the classification only takes the most evident differences into account.

In comparison to a sandy riverbed, the thermal conductivity of peat is low and the heat capacity high, thus the damping of the thermal signal with depth is strong. Since the biggest changes in temperature occur close to the interface, temperature measurements at shallow depths are necessary. The interface between riverbed and surface water, however, is often not easy to define. Hence, the techniques of collecting field data in peat environments should be subject of future improvement. An investigation of the soil parameters with laboratory tests, a detailed assessment of the stratigraphy of the riverbed and field measurements with an increased spatial resolution are likely to further improve the model output. A classification of the parameters as described, however, will be always necessary. An additional challenge for field investigations is the fact that protected wetlands obviously are not easily accessible and may also underlie legal or environmental restrictions that can hamper scientific investigation.

The introduction of interpolated temperature time series defining the upper boundary of the transient thermal model of the T-stick measurements may lead to biases. Moreover, the real exchange fluxes are not constant over time (Fig. 10), influencing the thermal pattern in the riverbed. Consequently, this may influence the flux estimates integrated over long periods of time, especially when only a few measured temperature profiles are available to fit the model (Fig. 5). Finally, the estimated fluxes are in general fairly low, which can magnify the influence of uncertainties on the simulated fluxes. Hence, we expect that the accuracy of the modelled results in the Biebrza River is lower than of comparable works on sandy riverbeds or other more homogeneous environments, as presented by Anibas et al. $(2009,2011)$ or Dujardin et al. (2011). The presented study therefore represents a first level investigation of the exchange fluxes in the area. Furthermore, STRIVE is a one-dimensional vertical model and hence cannot give any insight on lateral or longitudinal flow vectors within the riverbed (Fairley and Nicholson, 2005). The obtained RMSE values of around $0.45^{\circ} \mathrm{C}$ have, however, an acceptable magnitude. 
As stated by Cardenas (2008) or Boano et al. (2009), hydromorphology seems to play a key role for the hyporheic exchange. By interpolating the scattered point estimates on a reach scale (Figs. $6 \mathrm{~b}$ and 8 ), the role of morphologic features and net exchange rates can be studied. Statistical tests show the dependence of the exchange flux to the distance of the measurement point to the slope crack (Fig. 8b) and the influence of meanders on the groundwater-surface water exchange. Factors like at the edges of meanders are closer to the morainic plateau, have a higher conductive underground and that groundwater flow lines are converging towards them are indentified to control the spatial variations. These effects are stronger for the right side of the fluvial plain and are visible at the upper and lower end of the measured section where the river approaches the slope crack (Fig. 8b). We consequently regard the right bank of the river stretch as being responsible for the greater share of groundwater discharge into the river.

By positive feedback processes, groundwater-surface water exchange thus could have an influence on the formation of meanders or on the soil composition of the riverbed. The morphology of the river therefore will not just influence the quantity of the exchange fluxes - they themselves could influence the geomorphology.

Hydrological models (van Loon et al., 2009) of the area suggest surficial lateral flows across the fluvial plain. A pure vertical groundwater discharge indeed cannot explain the magnitude of river discharge. In general, the surface water discharge measurements of De Doncker et al. (2009) and the interpolated net groundwater fluxes (Fig. 8) have a comparable distribution. Exfiltration and infiltration coexist side by side along the reach. The infiltration is, however, fairly small and limited to nine percent of the surface of the river reach.

Transient thermal simulations with STRIVE can be performed on different time scales. Periods of months or seasons are feasible, assuming relative constant groundwater fluxes; time scales of less than a week are problematic because of initialization errors and limited data points to fit the model (Dujardin et al., 2011). When compared with head measurements from piezometer nest No. 4, the thermal models perform well. Short flux peaks, however, cannot be reproduced with the thermal model.

Since it is often difficult to get reliable values for the vertical hydraulic conductivity $K_{\mathrm{v}}$ of riverbeds, especially for heterogeneous peat soils, STRIVE is capable of connecting information of hydraulic gradients with modeled exchange fluxes for its estimation. We found $K_{\mathrm{v}}$ values varying over one magnitude along the reach. Since the variation of fluxes does not correspond with these differences, they are more related to different head gradients than to changes in conductivity.

The quantitative information of groundwater-surface water interaction or simply the measured temperatures can be used to improve the parameterization and calibration of modelled hydrological or ecological transport, retention and reaction processes for the Biebrza River and its wetlands. This will not only improve the understanding of the functioning of the site but further establish the Biebrza National Park as a hydro-ecologic reference area of worldwide significance (Chormański et al., 2009; Dabrowska-Zielinska et al., 2009). A better understanding of the interaction processes between the river and its adjacent wetlands and the hyporheic zone of this particular ecosystem will help to develop unerring procedures for its management and conservation - practices which can then be transferred to other locations where protection or restoration efforts are needed.

Acknowledgements. Financial support from the Research Foundation-Flanders for the work on the Biebrza River as part of the project "A fundamental study on exchange processes in river ecosystems" (G.0306.04) was greatly appreciated. Further support was received from the Belgian Science Policy Office in the framework of the MAMUD (SR/00/105), FRAC-WECO (SD/TE/02) projects and grants of the Polish Ministry of Science and Higher Education (N305 05232/1917) and the Flemish Ministry of Education. We would also like to thank Jan Szatyłowicz for the soil expertise and Andrzej Brandyk, Jef Dams and Tomasz Nowakowski for their invaluable help in the field. Finally we pay regards to Elga Salvadore for critically checking the manuscript and to Daniel O. Olago and an anonymous referee for their valuable comments.

Edited by: A. Opere

\section{References}

Anderson, M. P.: Heat as a Groundwater Tracer, Ground Water, 43, 951-968, 2005.

Anderson, M. P. and Wilson, J. L.: Groundwater fluxes across interfaces, Tech. Rep. 0-309-09113-6, National Research Council of the National Academies (NRC), Committee on Hydrologic Science, Washington, D.C., 2004.

Anibas, C., Fleckenstein, J., Volze, N., Buis, K., Verhoeven, R., Meire, P., and Batelaan, O.: Transient or steady-state? Using vertical temperature profiles to quantify groundwatersurface water exchange, Hydrol. Process., 23, 2165-2177, doi:10.1002/hyp.7289, 2009.

Anibas, C., Buis, K., Verhoeven, R., Meire, P., and Batelaan, O.: A simple thermal mapping method for seasonal spatial patterns of groundwater-surface water interaction, J. Hydrol., 397, 93-104, doi:10.1016/j.jhydrol.2010.11.036, 2011.

Banaszuk, H.: The protection programme of the Biebrza National Park, Statement of protection of inanimate nature and soils resources and values (manuscript in polish and GIS database), Tech. Rep., 2000.

Batelaan, O., Smedt, F. D., and Triest, L.: Regional groundwater discharge: phreatophyte mapping, groundwater modelling and impact analysis of land-use change, J. Hydrol., 275, 86-108, 2003.

Baxter, C., Hauer, F. R., and Woessner, W. W.: Measuring groundwater-stream water exchnage: New techniques for installing minipiezometers and estimating hydraulic conductivity, T. Am. Fish., 132, 493-502, 2003. 
Becker, M. W., Georgian, T., Ambrose, H., Siniscalchi, J., and Fredrick, K.: Estimating flow and flux of groundwater discharge using water temperature and velocity, J. Hydrol., 296, 221-233, doi:10.1016/j.jhydrol.2004.03.025, 2004.

Ber, A.: Polish Pleistocene stratigraphy - A review of interglacial stratotypes, Neth. J. Geosci., 84, 61-76, 2005.

Boano, F., Poggi, D., Revelli, R., and Ridolfi, L.: Gravity-driven water exchange between streams and hyporheic zones, Geophys. Res. Lett., 36, L20402, doi:10.1029/2009GL040147, 2009.

Boulton, A. J., Findlay, S., Marmonier, P., Stanley, B. H., and Valett, H. M.: The functional significance of the hyporheic zone in streams and rivers, Ann. Rev. Ecol. Syst., 29, 59-81, 1998.

Boulton, A. J., Datry, T., Kasahara, T., Mutz, M., and Stanford, J. A.: Ecology and management of the hyporheic zone: streamgroundwater interactions of running waters and their floodplains, J. N. Am. Benthol. Soc., 29, 26-40, doi:10.1899/08-017.1, 2010.

Bracken, L. J. and Croke, J.: The concept of hydrological connectivity and its contribution to understanding runoffdominated geomorphic systems, Hydrol. Process., 21, 17491763, doi:10.1002/hyp.6313, 2007.

Brunke, M. and Gonser, T.: The ecological significance of exchange processes between rivers and groundwater, Freshwater Biol., 37, 1-33, 1997.

Buis, K., Anibas, C., Bal, K., Banasiak, R., Donker, L. D., Smet, N. D., Gerard, M., van Belleghem, S., Batelaan, O., Troch, P., Verhoeven, R., and Meire, P.: Fundamentele studie van uitwisselingsprocessen in rivierecosystemen - Geïntegreerde modelontwikkeling, Water-Tijdschrift over integraal waterbeleid, Boechout, Belgium, 32, 51-54, 2008.

Byczkowski, A. and Kiciński, T.: Surface water in the Biebrza River drainage basin, Polish Ecol. Stud., 10, 271-299, 1984.

Cardenas, M. B.: The effect of river bend morphology on flow and timescales of surface water-groundwater exchange across pointbars, J. Hydrol., 362, 134-141, doi:10.1016/j.jhydrol.2008.08.018, 2008.

Cey, B. B., Rudolph, D. L., Parkin, G. W., and Aravena, R.: Quantifying groundwater discharge to a small perennial stream in southern Ontario, Canada, J. Hydrol., 210, 21-37, 1998.

Chen, X. H.: Measurement of streambed hydraulic conductivity and its anisotropy, Environ. Geol., 39, 1317-1324, 2000.

Chormański, J. and Batelaan, O.: Application of the WetSpa distributed hydrological model for catchment with signiphicant contribution of organic soil, Upper Biebrza case study, Ann. Warsaw Univ. of Life Sci. - SGGW, Land Reclamation, 43, 25-35, 2011.

Chormański, J., Kardel, I., Światek, D., Grygoruk, M., and Okruszko, T.: Hydroinformatics in Hydrology, Hydrogeology and Water Resources, vol. 331 of IAHS Publ., chap. Management Support System for wetlands protection: Red Bog and Lower Biebrza Valley case study, IAHS, Wallingford, UK, 423-431, 2009.

Chormański, J., Okruszko, T., Ignar, S., Batelaan, O., Rebel, K. T., and Wassen, M. J.: Flood mapping with remote sensing and hydrochemistry: A new method to distinguish the origin of flood water during floods, Ecol. Eng., 37, 1334-1349, doi:10.1016/j.ecoleng.2011.03.016, 2011.

Chou, P.: Modelling water exchange in the hyporheic zone between river and aquifer by laboratory experiments and numerical simulations, Ph.D. thesis, K. U. Leuven, Arenberg Doctoral School of Sciencem Engineering \& Technology, 2009.
Churski, T. and Szuniewicz, J.: Towards protection and sustainable use of the Biebrza Wetlands: Exchange and integration of research results for the benefit of a Polish-Dutch Joint Research Plan 3A, chap. Hydrogenic soils in the Biebrza valley and their physic-hydrological properties, IMUZ, Falenty, Poland, 185-206, 1994.

Conant, B.: Delineating and Quantifying Ground Water Discharge Zones Using Streambed Temperatures, Ground Water, 42, 243 257, 2004.

Constantz, J.: Interaction between stream temperature, streamflow, and groundwater exchanges in alpine streams, Water Resour. Res, 34, 1609-1615, doi:10.1029/98WR00998, 1998.

Constantz, J.: Heat as a tracer to determine streambed water exchanges, Water Resour. Res., 44, W00D10, doi:10.1029/2008WR006996, 2008.

Côté, J. and Konrad, J. M.: A generalized thermal conductivity model for soils and construction materials, Can. Geotech. J., 42, 443-458, doi:10.1139/T04-106, 2005.

Dabrowska-Zielinska, K., Gruszczynska, M., Lewinski, S., Hoscilo, A., and Bojanowski, J.: Application of remote and in situ information to the management of wetlands in Poland, J. Environ. Manage., 90, 2261-2269, 2009.

De Doncker, L., Troch, P., Verhoeven, R., Bal, K., Meire, P., and Quintelier, J.: Determination of the Manningroughness coefficient influenced by vegetation in the river Aa and Biebrza River, Environ. Fluid Mech., 9, 549-567, doi:10.1007/s10652009-9149-0, 2009.

Dujardin, J., Batelaan, O., Canters, F., Boel, S., Anibas, C., and Bronders, J.: Improving surface-subsurface water budgeting using high resolution satellite imagery applied on a brownfield, Sci. Total Environ., 409, 800-809, doi:10.1016/j.scitotenv.2010.10.055, 2011.

European Commission: Directive 92/43/EEC on the Conservation of natural habitats and of wild fauna and flora, Official Journal of the European Community, L206, 7-50, 1992.

European Commission: Directive 2000/60/EC of the European Parliament and of the Council establishing a framework for Community action in the field of water policy, Official Journal of the European Community, L327, 1-72, 2000.

Fairley, J. P. and Nicholson, K. N.: Imaging lateral groundwater flow in the shallow subsurface using stochastic temperature fields, J. Hydrol., 321, 276-285, doi:10.1016/j.jhydrol.2005.08.017, 2005.

Farouki, O. T.: Thermal Properties of Soils, TransTech Publications, Vol. 11, Clausthal-Zellerfeld, Germany, 1986.

Ferguson, G. and Bense, V.: Uncertainty in 1D Heat-Flow Analysis to Estimate Groundwater Discharge to a Stream, Ground Water, 49, 336-347, doi:10.1111/j.1745-6584.2010.00735.x, 2011.

Fetter, C. W.: Applied Hydrogeology, 4th Edn., Prentice Hall, Upper Saddle River, N.J., 2001.

Fisher, S. G., Grimm, N. B., Marti, B., Holmes, R. M., and Jones Jr., J. B.: Material Spiraling in stream Corridors: A telescoping Ecosystem model, Ecosystems, 1, 19-34, 1998.

Fleckenstein, J., Niswonger, R. G., and Fogg, G. B.: RiverAquifer Interactions, Geologic Heterogeneity, and Low-Flow Management, Groundwater, 44, 837-852, doi:10.1111/j.17456584.2006.00190.x, 2006. 
Gnatowski, T., Szatylowicz, J., Brandyk, T., and Kechavarzi, C.: Hydraulic properties of fen peat soils in Poland, Geoderma, 154, 188-195, doi:10.1016/j.geoderma.2009.02.021, 2010.

Hayashi, M. and Rosenberry, D. O.: Effects of Groundwater Exchange on the Hydrology and Ecology of Surface Water, Ground Water, 40, 309-316, 2002.

Hooftman, D. A. P., van Kleunen, M., and Diemer, M.: Effects of habitat fragmentation on the fitness of two common wetland species, Carex davalliana and Succisa pratensis, Oecologia, 134, 350-359, doi:10.1007/s00442-002-1096-0, 2003.

Hunt, R. J., Krabbenhoft, D. P., and Anderson, M. P.: Groundwater inflow measurements in wetland systems, Water Resour. Res, 32, 495-507, 1996.

Kalbus, E., Reinstorf, F., and Schirmer, M.: Measuring methods for groundwater - surface water interactions: a review, Hydrol. Earth Syst. Sci., 10, 873-887, doi:10.5194/hess-10-873-2006, 2006.

Kalbus, E., Schmidt, C., Reinstorf, F., Krieg, R., and Schirmer, M.: How streambed temperatures can contribute to the determination of aquifer heterogeneity, Grundwasser, 13, 91-100, doi:10.1007/s00767-008-0066-9, 2008.

Keery, J., Binley, A., Crook, N., and Smith, J. W. N.: Temporal and spatial variability of groundwater-surface water fluxes: Development and application of an analytical method using temperature time series, J. Hydrol., 336, 1-16, doi:10.1016/j.jhydrol.2006.12.003, 2007.

Kossowska-Cezak, U.: Climate of the Biebrza ice-margin Valley, Polish Ecol. Stud., 10, 253-270, 1984.

Lamers, L. P. M., Smolders, A. J. P., and Roelofs, J. G. M.: The restoration of fens in the Netherlands, Hydrobiologia, 478, 107130, 2002.

Lapham, W. M.: Use of temperature profiles beneath streams to determine rates of vertical ground-water flow and vertical hydraulic conductivity, Water-Supply Paper 2337, US Geological Survey, Denver, CO, 1989.

Lautz, L. K.: Impacts of nonideal field conditions on vertical water velocity estimates from streambed temperature time series, Water Resour. Res., 46, W01509, doi:10.1029/2009WR007917, 2010.

Lee, D. R.: Device for Measuring Seepage Flux in Lakes and Estuaries, Limnol. Oceanogr., 22, 140-147, 1977.

Lexartza-Artza, I. and Wainwright, J.: Hydrological connectivity: Linking concepts with practical implications, Catena, 79, 146152, doi:10.1016/j.catena.2009.07.001, 2009.

McClain, M. B., Boyer, B. W., Dent, C. L., Gergel, S. B., Grimm, N. B., Groffmann, P. M., Hart, S. C., Harvey, J. W., Johnston, C. A., Mayorga, B., McDowell, W. H., and Pinay, G.: Biogeochemical Hot Spots and Hot Moments at the interface of Terrestrial and Aquatic Ecosystems, Ecosystems, 6, 301-312, 2003.

Murdoch, L. C. and Kelly, S. B.: Factors affecting the performance of conventional seepage meters, Water Resour. Res., 39, 1163, doi:10.1029/2002WR001347, 2003.

Okruszko, T., Chormański, J., and Światek, D.: Climate Variability and Change-Hydrological Impacts, vol. 308 of IAHS Publ., chap. Interaction between surface and groundwater in the flooding of riparian wetlands: Biebrza wetlands case study, IAHS, Wallingford, UK, 573-578, 2006.

Oświt, J.: Formation, structure and development of Biebrza Valley peatlands; Bagna Biebrzanskie (Biebrza wetlands), in: Zeszyty Problemowe Postepow Nauk Rolniczych, vol. 372 of Issue Papers of Progress in Agricultural Sciences, 185-218, 1994.
Ovaskainen, O. and Hanski, I.: From individual behavior to metapopulation dynamics: Unifying the patchy population and classic metapopulation models, Am. Nat., 164, 364-377, 2004.

Pajnowska, H. P. R. and Wiencław, W.: Groundwaters of the Biebrza Valley, Polish Ecological studies, 10, 301-311, 1984.

Pałczyński, A.: Natural differentiation of plant communities in relation to hydrological conditions of the Biebrza Valley, Polish Ecol. Stud., 10, 347-385, 1984.

Pałczyński, A.: Succession trends in plant communities of the Biebrza Valley, Polish Ecol. Stud., 11, 5-50, 1985.

Peters-Lidard, C. D., Blackburn, E., Liang, X., and Wood, E. F.: The Effect of Soil Thermal Conductivity Parameterization on Surface Energy Fluxes and Temperatures, J. Atmos. Sci., 55, 1209-1224, 1998.

Pringle, C. M.: Hydrologic connectivity and the management of biological reserves: A global perspective, Ecol. Appl., 11, 981998, 2001.

Ramsar Convention Secretariat: List of Wetlands of International Importance, Gland, Switzerland, 2008.

Schmidt, C., Bayer-Raich, M., and Schirmer, M.: Characterization of spatial heterogeneity of groundwater-stream water interactions using multiple depth streambed temperature measurements at the reach scale, Hydrol. Earth Syst. Sci., 10, 849-859, doi:10.5194/hess-10-849-2006, 2006.

Schmidt, C., Conant, B., Bayer-Raich, M., and Schirmer, M.: Evaluation and field-scale application of an analytical method to quantify groundwater discharge using mapped streambed temperatures, J. Hydrol., 347, 292-307, doi:10.1016/j.jhydrol.2007.08.022, 2007.

Schornberg, C., Schmidt, C., Kalbus, E., and Fleckenstein, J. H.: Simulating the effects of geologic heterogeneity and transient boundary conditions on streambed temperatures - Implications for temperature-based water flux calculations, Adv. Water Resour., 33, 1309-1319, doi:10.1016/j.advwatres.2010.04.007, 2010.

Schot, P. and Winter, T.: Groundwater-surface water interactions in wetlands for integrated water resources management-Preface, J. Hydrol., 320, 261-263, doi:10.1016/j.jhydrol.2005.07.021, 2006.

Schwärzel, K., Renger, M., Sauerbrey, R., and Wessolek, G.: Soil physical characteristics of peat soils, J. Plant Nutr. Soil Sci., 165, 479-486, 2002.

Smith, J. W. N.: Groundwater-surface water interactions in the hyporheic zone, Science Report SC030155/SR1, Environment Agency, Bristol, UK, 2005.

Smolders, A. J. P., Lamers, L. P. M., Lucassen, E. C. H. E. T., van der Velde, G., and Roelofs, J. G. M.: Internal eutrophication: how it works and what to do about it - a review, Chem. Ecol., 22, 93-111, 2006.

Smolders, A. J. P., Lucassen, E. C. H. E. T., Bobbink, R., Roelofs, J. G. M., and Lamers, L. P. M.: How nitrate leaching from agricultural lands provokes phosphate eutrophication in groundwater fed wetlands: the sulphur bridge, Biogeochemistry, 98, 1-7, doi:10.1007/s10533-009-9387-8, 2010.

Soetaert, K., deClippele, V., and Herman, P.: FEMME, a flexible environment for mathematically modeling the environment, Ecol. Model., 151, 177-193, 2002. 
Soetaert, K., deClippele, V., and Herman, P.: FEMME, a flexible environment for mathematically modelling the environment, Netherlands Institute of Ecology, Center for Estuarine and Marine ecology, Yerseke, The Netherlands, 2004.

Sophocleous, M.: Interactions between groundwater and surface water: the state of the science, Hydrogeol. J., 10, 52-67, 2002.

Stallman, S.: Steady one-dimensional fluid flow in the semi-infinite porous medium with sinusoidal surface temperature, J. Geophys. Res., 70, 2821-2827, doi:10.1007/s10533-009-9387-8, 1965.

Stonestrom, D. A. and Constantz, J.: Heat as a tool for Studying the Movement of Groundwater near Streams, Circular 1260, USGS, Reston, Virginia, 2003.

Succow, M. and Joosten, H.: Landschaftsökologische Moorkunde, 2nd Edn., Schweizerbart, Stuttgart, Germany, 2001.

Tetzlaff, D., Soulsby, C., Bacon, P. J., Youngson, A. F., Gibbins, C., and Malcolm, I. A.: Connectivity between landscapes and riverscapes-a unifying theme in integrating hydrology and ecology in catchment science?, Hydrol. Process., 21, 1385-1389, doi:10.1002/hyp.6701, 2007.

Tockner, K. and Stanford, J. A.: Riverine flood plains: present and future trends, Enivron. Conserv., 29, 308-330, doi:10.1017/S037689290200022X, 2002.

Triska, F. J., Duff, J. H., and Avanzino, R. J.: The role of water exchange between a stream channel and its hyporheic zone in nitrogen cycling at the terrestrial aquatic interface, Hydrobiologica, 251, 167-184, 1993.

Van Diggelen, R., Middleton, B., Bakker, J., Grootjans, A., and Wassen, M.: Fens and floodplains of the temperate zone: Present status, threats, conservation and restoration, Appl. Veg. Sci., 9, 157-162, 2006.

van Loon, A. H., Schot, P. P., Griffioen, J., Bierkens, M. F. P., Batelaan, O., and Wassen, M. J.: Throughflow as a determining factor for habitat contiguity in a near-natural fen, J. Hydrol., 379, 3040, 2009.
Vaughan, L. P., Diamond, M., Gurnell, A. M., Hall, K. A., Jenkins, A., Milner, N. J., Naylor, L. A., Sear, D. A., Woodward, G., and Ormerod, S. J.: Integrating ecology with hydromorphology: a priority for river science and management, Aquatic Conserv., Mar. Freshwater Ecosyst., 19, 113-125, doi:10.1002/aqc.895, 2009.

Ward, J. V.: An expansive perspective of riverine land- scapes: pattern and process across scales, River Ecosyst., 6, 52-60, 1997.

Wassen, M., Okruszko, T., Kardel, I., Chormański, J., Światek, D., Mioduszewski, W., Bleuten, W., Querner, E. P., Kahloun, M. E., Batelaan, O., and Meire, P.: Ecological Studies: Wetlands: Functioning, biodiversity conservation, and restoration, chap. Eco-hydrological functioning of the Biebrza Wetlands: Lessons for the conservation and restoration of deteriorated wetlands, Springer, New York, USA, 285-310, 2006.

Wassen, M. J. and Joosten, J. H. J.: In search of a hydrological explanation for vegetation changes along a fen gradient in the Biebrza Upper Basin (Poland), Vegetatio, 124, 191-209, 1996.

Weight, W. D. and Sonderegger, J. L.: Manual of applied field hydrogeology, McGraw-Hill, New York, USA, 224-253, 2001.

With, K. A., Gardner, R. H., and Turner, M.: Landscape connectivity and population distributions in heterogeneous environments, OIKOS, 78, 151-169, doi:10.2307/3545811, 1997.

Woessner, W. W.: Stream and Fluvial Plain Ground Water Interactions: Rescaling Hydrogeologic Thought, Ground Water, 38, 423-429, 2000.

Żurek, S.: Relief, geologic structure and hydrography of the Biebrza ice-marginal valley, Polish Ecol. Stud., 10, 39-251, 1984. 